\title{
Linguistic innovation, political centralization and economic integration in the Kongo kingdom
}

\section{Reconstructing the spread of prefix reduction*}

\author{
Koen Bostoen \& Gilles-Maurice de Schryver \\ Ghent University, Université libre de Bruxelles / Ghent University, \\ University of Pretoria
}

\begin{abstract}
In this article we reconstruct the actuation and transmission of a phonological innovation known as prefix reduction within the Kikongo language cluster situated in the wider Lower Congo region of Central Africa. We argue that this change spread from a focal area coinciding with the heartland of the Kongo kingdom as a classical process of dialectal diffusion. Thanks to a unique Kikongo corpus that starts in the 17th century, we can provide diachronic empirical evidence for different phases of the process, which has been otherwise difficult, if not impossible, in Bantu historical linguistics. What is more, and also quite exceptional in African linguistics, we have fairly good insight into the 'social ecology' of this language change and argue that political centralization and economic integration within the realm of the Kongo kingdom facilitated such a contact-induced diffusion between closely-related language varieties.
\end{abstract}

Keywords: Kikongo; Bantu; Kongo kingdom; historical linguistics; diachronic corpus; prefix syncope; sound change; contact-induced dialectal diffusion

\footnotetext{
* Our thanks go to Jasper De Kind who first observed the start of prefix syncope in the Vocabularium Congense (Van Gheel 1652) as part of his MA research (De Kind 2012). We also wish to thank Manon Denolf, Wout Goossens, Magalie Kisukurume, Maarten Merveille, Nick Rahier and Caitlin Sabbe, Bachelors students in African Languages and Cultures at Ghent University, who mined some of the data used here in an electronic Kikongo corpus made available to them as part of a research course on African language documentation and description taught by Gilles-Maurice de Schryver. Furthermore, Jasper De Kind, Birgit Ricquier, Sebastian Dom and three peer reviewers provided very helpful feedback. The usual disclaimers apply. The research for this article has been funded by the European Research Council through a Starting Grant (KongoKing, Grant No. 284126) and the Special Research Fund of Ghent University.
} 


\section{Introduction}

In Bantu-speaking Africa - and in most of Sub-Saharan Africa more generally examining language change is hardly ever possible on the basis of historical empirical evidence. Diachronic corpus-based research on Bantu languages is only nascent and has to rely on corpora of limited time-depth, i.e. the late 19th century at the earliest (e.g. De Schryver \& Gauton 2002; Kawalya et al. 2014). One Bantu language truly exceptional in this regard is Kikongo, spoken in the Lower Congo region of Central Africa. The earliest available Bantu data originate from that language and date back to the 17th century (Doke 1935). The first texts from the Lower Congo region, all in Roman script, include a Kikongo catechism from 1624 (Bontinck \& Ndembe Nsasi 1978), a Latin-Spanish-Kikongo dictionary manuscript from 1652 (De Kind et al. 2012) and a Kikongo grammar from 1659 (Guinness 1882). They reflect the variety of Kikongo spoken by the local political upper class, since European missionaries produced them with the help of native speakers from that elite. Foreign clergy were strongly attached to Kongo nobility ever since the late 15th century when this Central African kingdom made its entrance into transatlantic history. These 17th-century Kikongo documents result from an increasing need for language acquisition felt by incoming European clergy who wanted to become more independent from local interpreters on which 15th- and 16th-century missionary activities had strongly relied (Brinkman 2014).

The only Bantu language documented with a similar time depth is neighboring Kimbundu, of which the first text, also a catechism, dates back to 1643 (Doke 1935). The earliest surviving language documents from the East African coast, i.e. Kiswahili texts written in Arabic script, do not date further back than the mid-18th century, although the language in which they are written might be older (Knappert 1971:5). Such diachronic Bantu documents have an unequalled historical-linguistic potential in that they allow for the comparison of successive diachronic stages of one and the same language over a time span of several centuries. Historical Bantu linguistics has a strong comparative tradition, so researchers never properly exploited this potential. Illustrative in this respect is the fact that Nurse \& Hinnebusch (1993) do not even integrate diachronic data in their magisterial comparative study of Kiswahili and its closest relatives, without a doubt one of the most comprehensive historical-linguistic studies of a Bantu language group.

A systematic study of diachronic language change on the basis of historical empirical evidence covering a period of about 400 years, as presented in this article for Kikongo, is usually impossible in Bantu. We focus here on one specific innovation in one specific Bantu language, i.e. prefix reduction in Kikongo, but our reconstruction of its diachronic evolution can be a model for new ways of approaching language change more generally in early documented Bantu and 
other African languages. We argue that the historical evidence presented in this article suffices to show that prefix reduction in Kikongo is an innovation that started in the heartland of the Kongo kingdom, from where it spread to more peripheral areas.

We provide not only historical evidence for a contact-induced diffusion of language innovation between closely-related language varieties - in itself rather uncommon in Bantu linguistics - but also try to reconstruct the social setting against which this historical change took place. The reconstruction of language evolution in Africa usually happens without access to what Mufwene (2001) calls 'the ecology of language evolution', i.e. the environmental, social, cultural and historical factors that conditioned linguistic change. Because of its early contacts with literate Europe, the Lower Congo region also stands out in that respect. No other region in Central Africa is historically better documented and the history of the Kongo kingdom is better reconstructed than that of any other Central African polity. Thanks to the erudition of several generations of historians (e.g. Van Wing 1921; Cuvelier 1946; Balandier 1965; Randles 1968; Thornton 1983; Hilton 1985), we have unequalled information about and insights into the area's history over the last 500 years. This allows us not only to present here evidence for both the period when prefix reduction started and the geographical area from where it originated and subsequently spread, but also to provide a tentative reconstruction of its 'social ecology'.

In $\$ 2$ we present the Kikongo language cluster (KLC) and the diachronic Kikongo language corpus on which this study is based. In $\$ 3$ we discuss the phenomenon of $m u$ - $/ m i$ - prefix syncope in Kikongo, and in $\$ 4$ we give its current-day spread within the KLC. In $\$ 5$ we reconstruct the diachronic evolution of this morphological change, and in $\$ 6$ we show how it exemplifies a broader phenomenon of prefix reduction that most likely started from a focal area in the southern part of the KLC as a classical example of dialectal diffusion. In $\$ 7$ we develop how political centralization in the late 16 th and early 17 th centuries may have facilitated such a contact-induced diffusion between closely-related language varieties. Conclusions are presented in $\$ 8$.

\section{Kikongo language corpora}

The Lower Congo region is home to the Bantu language known as Kikongo, which is actually a large cluster of closely related language varieties spoken in four different countries: Angola (including Cabinda), the DRC, the Republic of the Congo and Gabon. This vast cluster of regiolects manifests a family resemblance structure in the sense that adjacent varieties are mutually intelligible, but 
varieties at the extreme ends of the chain are not. Such a chain of mutual intelligibility is commonly known as a 'geographical dialect continuum' (Chambers \& Trudgill 1998:6). Kikongo could be considered as such a dialect continuum, but we prefer to speak of the 'Kikongo language cluster', abbreviated here as KLC, because certain outliers share no more than about 40 to $50 \%$ of cognate basic vocabulary. In addition to the numerous regiolects, a creolized form of Kikongo, known as Kituba, Monokutuba or Kikongo ya leta, is spoken in several urban centers in the DRC and the Republic of the Congo (Mufwene 2013; Samarin 2013). This vehicular language will not be considered here. The KongoKing research group has identified some thirty different present-day Kikongo regiolects from the four countries. As shown on Map 3 (maps are included as addenda), these varieties are reasonably well distributed over the study area. We therefore assume them to be representative of the linguistic variation that exists within the KLC.

Given the current state of documentation and our still-limited knowledge of the region's dialectology, we tend to treat the varieties selected as 'doculects', i.e. linguistic varieties as they are documented in a given resource (Cysouw \& Good 2013:342). The documentation available for each of them from the late 19th century onwards is quite variable, both quantitatively and qualitatively. In addition, there are older language sources from two well-confined sub-regions. The 17th-century sources mentioned in the introduction originate from the area around Mbanza Kongo, the former capital of the Kongo kingdom, in the southern part of the KLC (cf. Map 1). The diachronic sequence in the western part of the KLC starts in the late 18th century. In an area historically known as Kakongo in present-day Cabinda (cf. Map 2), French missionaries produced several dictionary manuscripts and a grammar manuscript on the Kikongo variety spoken there in the 1770s (cf. Cuvelier 1953; Van Bulck 1954). Since 2012, the KongoKing research group has undertaken a systematic effort to collect and digitize this diachronic Kikongo documentation in order to make it accessible for corpus-based comparative research (De Kind et al. 2012; De Schryver et al. 2013; Drieghe 2014).

\section{Nasal prefix syncope in Kikongo: A synchronic description}

Noun class systems are a characteristic feature of Bantu languages, such as Kikongo, where nouns are generally categorized in different noun classes according to the prefixes they take in their singular and plural form and the agreement patterns they trigger on verbs and nominal modifiers (Katamba 2003). Noun 
prefixes generally have a CV shape, except in the so-called class 5, for which ${ }^{*}$ i- was reconstructed in Proto-Bantu, and classes 9 and 10, for which nonsyllabic homorganic nasal prefixes were reconstructed. Homorganic ${ }^{\star} \mathrm{N}$ - was also reconstructed for the verbal subject and object 1sG concord prefixes (Meeussen 1967). All Kikongo varieties have retained these non-syllabic homorganic nasal prefixes, as have most Bantu languages. However, several current-day Kikongo varieties have, in addition to this inherited nasal prefix set, a second set of nasal prefixes, i.e. the syllabic homorganic nasal prefixes of noun classes 1,3 and 4 as well as the class 1 object concord. These correspond to ProtoBantu prefixes reconstructed with a NV structure, i.e. ${ }^{*}$ mù- (classes 1 and 3) and ${ }^{*}$ mì- (class 4 ). The loss of the vowel in such sequences of nasal and vowel regularly gives rise to syllabic nasals in Bantu (Bell 1972; Nurse \& Hinnebusch 1993: 181-185; Hyman \& Ngunga 1997: 139ff). This sound change, which particularly targets unstressed medial vowels, is widespread in the world's languages and commonly known as 'syncope' in historical linguistics (Crowley \& Bowern 2010:28). Nurse \& Hinnebusch (1993:184), who notice this innovation in several Kiswahili varieties, call it 'syncopation'.

The original NV shape has actually not entirely disappeared from the language, as it still turns up in a number of well-defined phonological contexts. The examples in (1) illustrate this allomorphy in four different Kikongo varieties: Kisikongo (Ndonga Mfuwa 1995), Kindibu (Coene 1960), Kiyombe (De Grauwe 2009) and Kintandu (Daeleman 1983). The original prefix is maintained before noun stems beginning with a nasal-consonant (NC) cluster (1a) or with a vowel (1b) (see also De Kind 2012). Before a vowel having a different degree of aperture, the prefix vowel becomes a glide; otherwise a long vowel is observed. The prefix is only reduced to a syllabic nasal in front of consonant-initial stems (1c). The syncopated nasal prefixes are called 'homorganic', because they assimilate to the place of articulation of the following consonant. The nasal preceding the noun stem for "woman" is actually velar. According to common Kikongo orthographic rules the grapheme $\langle\mathrm{n}\rangle$ is adopted in both alveolar and velar NC clusters, but not in bilabial ones. We follow here the source spelling. In Kiyombe, the class 4 plural nominal prefix is not a simple syllabic nasal, but a compound form consisting of $m i$ - and the syncopated nasal prefix. Either the full plural prefix was added to the singular form including the syncopated singular prefix or the plural prefix also underwent syncope and its full form was subsequently reintroduced in front of the syncopated prefix. The latter would be the result of a morphological reanalysis motivated by the functional markedness of the plural. Marked functional categories tend to have an overt marker (Bell 1972:36, with reference to Greenberg 1966). 


\begin{tabular}{|c|c|c|c|c|c|c|c|}
\hline 1) & & KISIKONGO & KindibU & Кіуомве & KINTANDU & Class & Translation \\
\hline \multirow[t]{4}{*}{ a. _ $\mathrm{NC}$} & SG & múntù & muntu & muútu $^{1}$ & muuntu & 1 & "person" \\
\hline & PL & wántu & (b)antu & baátu & baantu & 2 & \\
\hline & SG & múndèlè & mundele & múndeela & mundéle & 3 & "white man" \\
\hline & PL & mîndèlè & mindele & mîndeela & mindéle & 4 & \\
\hline \multirow[t]{4}{*}{ b. $\_$V } & SG & mwánà & mwana & mwáana & mwaaná & 1 & "child" \\
\hline & PL & wàánà & bana & báana & baaná & 2 & \\
\hline & SG & mwivi & muivi & mwíivi & mwiifí & $1 \sim 3$ & "thief" \\
\hline & PL & & & (ba)míivi & beefí & $2 \sim 4$ & \\
\hline \multirow[t]{6}{*}{ c. $\_\mathrm{C}$} & SG & ykèntò & ykento & ykééto & j̀kéénto & 1 & "woman" \\
\hline & PL & bákèntò & bakento & bakééto & bakéénto & 2 & \\
\hline & SG & ntí & $n t i$ & $n t i ́$ & nití & 3 & "tree" \\
\hline & PL & ntí & $n t i$ & mintí & nití & 4 & \\
\hline & SG & $m v \dot{u}$ & $m v u$ & $m v u ́$ & mivú & 3 & "year" \\
\hline & PL & $m v \dot{u}$ & $m v u$ & mimvú & ǹvú & 4 & \\
\hline
\end{tabular}

The syllabicity of the nasal prefix of noun classes 1, 3 and 4 is not only implied by the fact that these are tone bearing units, as noted on the Kintandu examples in (1c). They also manifest morphophonological behavior that differs from the non-syllabic nasal prefixes of noun classes 9/10 and 1sG. (See the supplementary material online for a full exposition of this different linguistic behavior.)

On the other hand, both sets of nasal prefixes do have in common their homorganicity. In Bantu languages showing prefix syncope, the resulting syllabic nasal is however not always assimilated to the place of articulation of the stem-initial consonant (Bell 1972; Nurse \& Hinnebusch 1993: 184). This is also seen for two Kikongo varieties, namely Cisundi and Dihungu. For Cisundi, Futi $(2012: 72,75)$ reports that before consonants, the vowel /u/ of the /mu-/ prefix of classes 1 and 3 is deleted resulting in a syllabic $m$ - prefix, as shown in (2). The data from Atkins (1954: 148-150) for Dihungu shown in (3) is analogous.

(2)

Class 1
m'fyóote "black person"
m'tinu "king"
m'kama "wife"
m'fwiizi "widow"

Class 3

m’bákati "avocado tree"

m'koondo "baobab"

m’káaka "squirrel"

m'kata "cake"

(CISUNDI)

1. The stem-initial NC cluster is realized here as a simple oral consonant. This reflects a common sound change before voiceless consonants in Kiyombe which is often accompanied by aspiration of the voiceless consonant (De Grauwe 2009: XIII). 
(3) Class $1 / 2$ Class 3/4

(DIHUNGU)

m-khetu/a-khetu "woman/-en" m-koko/mi-koko "river(s)"

$m$-thu "person" m-zala/mi-zala "finger(s)"

The variation observed with respect to the homorganicity of syncopated nasal prefixes on a Bantu-wide level is thus also observed within the KLC. Such is the case regarding the prefix syncope hierarchy which Bell (1972) establishes in his Bantu-wide study comparing the reflexes of the Proto-Bantu noun class prefixes having a NV structure: ${ }^{*}$ mù- $>{ }^{*}$ mì- $>{ }^{*}$ mà-. High vowels are more frequently deleted in such sequences than the low central vowel - which is actually never syncopated - and the high back rounded vowel even more frequently than the high front unrounded vowel. Sharing the articulatory feature of lip-roundedness with the labial nasal, the high back vowel is more naturally absorbed by the preceding consonant. Within the KLC, there are no varieties which attest ${ }^{*}$ mì- syncope but not ${ }^{*}$ mù- syncope, but the opposite does occur. In a minority of Kikongo varieties, such as Dihungu in (3) and Civili of Mayumba (Gabon) in (4), the full noun prefix of class 4 is maintained under all circumstances (Ndinga-Koumba-Binza 2000).

(4)

\begin{tabular}{|c|c|c|}
\hline mívù/mívù & “year(s)" & (CIVILI-GABON) \\
\hline mifúnà/mífúnà & "package(s)" & \\
\hline$n t^{h} i / m i t i$ & "tree(s)" & \\
\hline$y^{\prime} k^{h} u ́ f i / m i ́ k u ́ f i$ & "anus(es)" & \\
\hline ǵk $k^{h}$ mbj̀/míkúmb̀̀ & "navel(s)" & \\
\hline ýk úti/míkúti & "spotted antelope(s)" & \\
\hline
\end{tabular}

In Kiyombi, spoken in the Republic of the Congo, the syncopated nasal prefixes of classes 1 and 3 also alternate with the full prefixes $b a$ - of class 2 and $m i$ - of class 4 (Mabiala 1999:40), as shown in (5). Thanks to the phonetic data provided by Mabiala (1992:27), we know that the syncopated nasal prefix is homorganic in spite of the orthography suggesting otherwise.

(5)

\begin{tabular}{|c|c|}
\hline ńvêsi/mîßêsi & "bone(s)" \\
\hline ńvîkà/báßîkà & "slave (s)" \\
\hline ńvindù/mîßindù & "slowness" \\
\hline Bindi & "calf/calves (leg)" \\
\hline ívî̀ngù/mîßìingù & "power" \\
\hline
\end{tabular}

(Кіуомві)

As seen in (1), the $m i$ - prefix may have undergone syncope in the Kiyombe variety of the DRC, but was subsequently reanalyzed as $m i N$ - resulting in a plural prefix that is distinctive again from the singular one. A similar reanalysis is observed in other Kikongo varieties, such as Kimboma in (6) and Cisundi in (7). We can assume that these varieties went through a phase of $m i$ - syncope. Strangely enough, 
the syncopated prefix in Cisundi seems to be homorganic in the plural form, but not in the singular form.

(6)

$\begin{array}{ll}\text { ntu/mintu } & \text { "head(s)" } \\ \text { nti/minti } & \text { "tree(s)" } \\ \text { nkanda/minkanda } & \text { "book(s)" } \\ & \\ m^{\prime} t i / m i n t i & \text { "tree(s)" } \\ m^{\prime} t i m a / m i n t i m a & \text { "heart(s)" } \\ \text { m'tu/mintu } & \text { "head(s)" } \\ \text { mintuutu } & \text { "bottles" } \\ \text { m'manga/mimmanga } & \text { "mango tree(s)" }\end{array}$

(Кімвома)

(Kisilu Meso 2001:7, 22)

(CISUNDI)

(Futi 2012:50, 72, 75)

From what precedes, it has become clear that the development of syllabic nasal prefixes from Proto-Bantu prefixes ${ }^{*}$ mù- of classes 1 and 3 and ${ }^{*}$ mì- of class 4 is not an innovation unique to Kikongo, but rather a common Bantu phenomenon motivated by articulatory naturalness. Moreover, its realization in Kikongo varies according to the same parameters as in other Bantu languages, i.e. homorganicity vs. non-homorganicity and the ${ }^{*}$ mù- $>{ }^{*}$ mì- $>{ }^{*}$ mà- syncope hierarchy. At the same time, its application is not purely phonetically motivated, since neither the locative prefix ${ }^{\star}$ mú- of class 18 nor $m u$-/mi- sequences within other morphemes are ever syncopated in Kikongo. This exception has also been reported elsewhere in Bantu (Bell 1972:38). In other languages, such as Kiswahili, syncope does also affect the $m u$-prefix of class 18 and $m u$ sequences in lexical items, such as -amka "wake up" <*-dàmok- (Nurse \& Hinnebusch 1993: 181). Syncopated class 18 locative prefixes also exist in Ciyao, where they are even homorganic: $n$ '- $t u$ - $p u$ “in the little bones", $n$ '-ci- $p i$ “in darkness", $y$ '-kadiilole "in the mirror" (Hyman \& Ngunga 1997:142). The fact that the locative marker is usually added to a noun's regular class prefix, as shown in the preceding Ciyao examples, likely accounts for its escape from syncope in several Bantu languages, amongst others Kikongo.

Syllabic nasal prefixes of classes 1 and 3 have been reported in the Kikongo varieties listed in (8), subdivided according to the preliminary phylogenetic clades which we could establish thanks to a large-scale phylogenetic study (De Schryver et al. 2013). Some of these lexically-based subgroups have been corroborated by independent, shared phonological and morphological innovations, such as the distinctive sound shift ${ }^{\star} \mathrm{p}>\gamma$ (Bostoen et al. 2013: 63-66) or several rearrangements in the tense-aspect system (Dom 2013:122-134). As discussed above, class $4 \mathrm{mi}$ also underwent syncope, except in Dihungu, Civili (Gabon) and Kiyombi. In Kimboma, Cisundi, Kiyombe, Kizobe, Cilinji, Cizali and Cimbala, the full mi- prefix precedes the syncopated nasal prefix as $\mathrm{miN}_{-}$. 


\begin{tabular}{|c|c|c|c|}
\hline (8) & South & $\begin{array}{l}\text { Kisikongo } \\
\text { Kimboma } \\
\text { Kisolongo } \\
\text { Kizombo } \\
\text { Kitsotso } \\
\text { Dihungu }\end{array}$ & $\begin{array}{l}\text { (Ndonga Mfuwa 1995) } \\
\text { (Kisilu Meso 2001) } \\
\text { (Tavares 1915, KongoKing (KK) fieldwork 2012, } \\
\text { Lembe-Masiala 2007) } \\
\text { (Carter \& Makondekwa 1987; Mpanzu 1994) } \\
\text { (Baka 1992) } \\
\text { (Atkins 1954) }\end{array}$ \\
\hline & Central & $\begin{array}{l}\text { Kindibu } \\
\text { Kimanyanga }\end{array}$ & $\begin{array}{l}\text { (Coene 1960) } \\
\text { (Laman 1912; Makokila 2012) }\end{array}$ \\
\hline & East & $\begin{array}{l}\text { Kintandu } \\
\text { Kimbata } \\
\text { Kimbeko } \\
\text { Kinkanu }\end{array}$ & $\begin{array}{l}\text { (Daeleman 1966) } \\
\text { (KK fieldwork 2012) } \\
\text { (KK fieldwork 2012) } \\
\text { (KK fieldwork 2012) }\end{array}$ \\
\hline & West & $\begin{array}{l}\text { Kiyombi } \\
\text { Civili (Gb) } \\
\text { Cisundi } \\
\text { Iwoyo } \\
\text { Kiyombe } \\
\text { Kizobe } \\
\text { Cilinji } \\
\text { Ciwoyo } \\
\text { Cizali } \\
\text { Cimbala }\end{array}$ & $\begin{array}{l}\text { (Mabiala 1992, 1999) } \\
\text { (Ndinga-Koumba-Binza 2000) } \\
\text { (Futi 2012) } \\
\text { (Mingas 1994) } \\
\text { (De Clercq 1921; De Grauwe 2009) } \\
\text { (KK fieldwork 2012) } \\
\text { (KK fieldwork 2012) } \\
\text { (KK fieldwork 2012) } \\
\text { (KK fieldwork 2012) } \\
\text { (KK fieldwork 2012) }\end{array}$ \\
\hline & North & Cilaadi & (Jacquot 1982a) \\
\hline
\end{tabular}

Nasal prefix syncope is thus widespread within the KLC, as can also be seen on Map 3. It is well attested in all sub-groups, except in the North cluster, where it is only attested, although not systematically, in Cilaadi (Jacquot 1982a: 150, Jacquot 1982b, Mabiala 1999), as can be seen in (9).

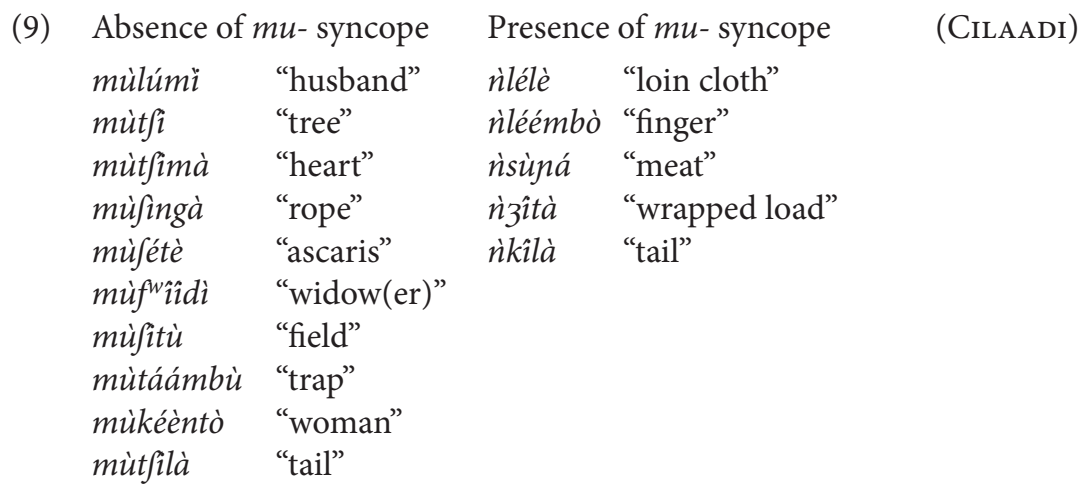


As shown in (10), the syncope of $m u$ - is also unsystematic in the southern Kikongo variety Kitsotso, spoken in the Uíge province of Angola between the centers of Damba and Mucaba (Baka 1992:2).

\begin{tabular}{|c|c|c|c|}
\hline Absence of $m u$ - sync & cope & Presence of $m u$ - sy & (KITSOTSO) \\
\hline mùkhé:thó/àkhé:thó & "woman/-en" & ǹkhé:thó/àkhé:thó & "woman/-en" \\
\hline mùkû:nlìàkû:nlì & "friend(s)" & ǹkû:nlì/àkû:nlì & "friend(s)" \\
\hline mùthú/mithú & "head(s)" & ìthú/rithú & "head(s)" \\
\hline mùthímà/mìthímà & "heart(s)" & nithímà/rithímà & "heart(s)" \\
\hline mùkílà/mikílà & "tail(s)" & ǹkílà/rikílà & "tail(s)" \\
\hline mùthí/mithí & "tree(s)" & ǹthí/ǹthí & "tree $(s) "$ \\
\hline ısíbù/misíbù & "curse(s)" & & \\
\hline
\end{tabular}

The variable occurrence of $m u$ - syncope in Cilaadi ties in rather well with the total absence of this phenomenon - including the absence of $m i$ - syncope - in its closest relatives, i.e. the other Kikongo varieties of the North cluster listed in (11).

$\begin{array}{lll}\text { North } & \text { Kibembe } & \text { (Nsayi 1984, Philippson \& Boungou 1999) } \\ \text { Kihangala } & \text { (Mabiala 1999) } \\ \text { Kikamba } & \text { (Bouka 1989) } \\ \text { Kidondo } & \text { (Mfoutou 1985) } \\ \text { Kikunyi } & \text { (Birgit Ricquier fieldwork 2010) } \\ \text { Kisundi } & \text { (N'landu Kitambika 1994; Mabiala 1999) }\end{array}$

All these varieties are spoken north of the border that separates the two Congos and have maintained the inherited form of the noun prefixes of classes 1, 3 and 4 in all contexts. Kitsotso together with Dihungu are the southernmost varieties of the KLC. Nasal prefix syncope also fails to take place in the so-called Shira-Punu group (Guthrie's B40 group) spoken in southern Gabon (Guthrie 1948; Maho 2009). These languages are traditionally not considered to be part of the KLC, but recent phylogenetic research indicates that they constitute a sub-unit of the West cluster and are most closely related to Civili and Kiyombi (De Schryver et al. 2013). As the Yipunu data (Bonneau 1956) and Yilumbu data (Mavoungou \& Plumel 2010) in (12) show, these outlier languages within the KLC have also retained the inherited full prefixes.

\begin{tabular}{llll} 
YIPUNU & \multicolumn{3}{l}{ YILUmbu } \\
mugatsi & "wife" & mughatsi "wife" \\
musatsi & "handy workman" & musa(li)tsi "workman, technician" \\
mubwandzi & "weaver" & mubwanga "weaver" \\
muganu & "debt" & mughanu "debt" \\
muru & "head" & muru & "loin cloth"
\end{tabular}

As regards the eastern and southern borders of the KLC, nasal prefix syncope does not occur in the immediately surrounding languages, except in Kikongo's nearest 
eastern neighbor, Kiyaka, spoken in the Kwango region of the Bandundu province (DRC). Together with its eastern neighbor, Kisuku, Kiyaka is phylogenetically closest to the core KLC (De Schryver et al. 2013). As shown in (13), while attested in Kiyaka (Van Den Eynde 1968:31-32), nasal prefix syncope is not attested in Kisuku (Piper 1977: 180-184).

(13)

\begin{tabular}{|c|c|c|c|c|c|}
\hline $\begin{array}{l}\text { KIYAKA } \\
\text { mbúumbi }\end{array}$ & (cl. 1) & "potter" & $\begin{array}{l}\text { KIsUKu } \\
\text { mulééki }\end{array}$ & (cl. 1) & "young child" \\
\hline nlókî & (cl. 1) & "witch" & muhika & (cl. 1) & "slave" \\
\hline nsádî & (cl. 1) & "worker" & mukusu & (cl. 3) & "rat" \\
\hline nléembo & (cl. 3) & "finger" & mutwá & (cl. 3) & "head" \\
\hline alele or milele & (cl. 4) & "cloths" & misuni & (cl. 4) & "meat" \\
\hline
\end{tabular}

Based on the current-day distribution of $m u$-/mi- syncope within the KLC, we can postulate a three-stage evolution as in Figure 1.

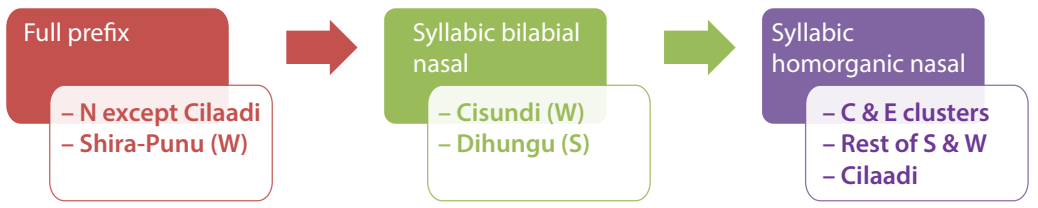

Figure 1. Postulated three-stage evolution of $m u-/ m i$ - syncope on the basis of synchronic evidence

\section{Mu-/mi- prefix reduction in Kikongo: A diachronic description}

In this section we examine the diachronic Kikongo corpus to assess whether the successive stages of the process, as presented in Figure 1, are observable through time.

\subsection{7th-century West Kikongo (1601)}

No genuine linguistic documentation is available for 17th-century West Kikongo. However, in his travel account the Dutch seafarer Pieter de Marees wrote down a number of words used by the inhabitants of Cape Lopez. This peninsula on the coast of Gabon, where the current-day town of Port-Gentil is situated, is actually just north of the KLC. Nevertheless, the list contains a mixture of words in Portuguese and in what could well be a variety of Kikongo, such as siomba (=-sumba) "to buy", quendo (= kwenda) "to go", -mona "to see", coria (= kulya) "to eat", mondello "Dutch nation" ("white man") and mokendofino "a beautiful woman". This last word is a blend of the Portuguese adjective fino "elegant" and the Kikongo word mukento 
"woman; wife" having the full prefix $m u$ - of class 1 . (See the supplementary material online for the full list cited by De Marees (1602).) None of these Bantu words occur in Myene, the cluster of languages currently spoken in the region of PortGentil (Raponda Walker 1934; Ambouroue 2007). It is thus very likely that De Marees recorded an early 17th-century West Kikongo variety, for which the word mokendo indicates that prefix reduction, if it had started at all, had certainly not been completed in this part of the KLC.

\subsection{7th-century South Kikongo (1624, 1652, 1659)}

The oldest full-fledged source of Kikongo data still available today is the Doutrina Christãa, a catechism by the Portuguese Jesuit Mateus Cardoso from 1624. It is the first book written in a Bantu language. Cardoso translated an existing Portuguese catechism, producing an interlinear Portuguese-Kikongo text, in close collaboration with the so-called mestres or catechist-interpreters whom he recruited among the autochthonous priests at the royal court in Mbanza Kongo (Bentley 1887: xi, Bontinck \& Ndembe Nsasi 1978:28). The Kongo capital was situated in current-day Northern Angola. Lexically-based diachronic phylogenetic research confirms that the Kikongo of the 1624 catechism is indeed most closely related to the South Kikongo varieties spoken there today (De Schryver et al. 2013). This oldest surviving Kikongo text contains several nouns belonging to classes $1 / 2$ and 3/4. In (14) we list, in order of frequency, the twelve most frequent cl. 1/2 and $3 / 4$ nouns, which occur at least 10 times, if one counts both the singular and plural forms. The nouns are presented in the original 1624 spelling, then followed in parentheses by the 20th-century orthography of Bontinck \& Ndembe Nsasi (1978), who issued a critical re-edition of the catechism and added both a French translation and a re-transcription of the original Kikongo text. As may be seen, none of these nouns, including those with a stem-initial oral consonant, underwent prefix reduction. As far as we can judge from the oldest surviving Kikongo source, the process of $m u$-/mi- syncope had not yet started in South Kikongo as spoken in the 1620 s.

\begin{tabular}{|c|c|c|c|c|c|}
\hline a. & $\begin{array}{l}\text { Singular } \\
\text { monho (monyo) }\end{array}$ & $\begin{array}{l}\text { Freq. } \\
89\end{array}$ & $\begin{array}{l}\text { Plural } \\
\text { mionho (mionyo) }\end{array}$ & $\begin{array}{l}\text { Freq. } \\
14\end{array}$ & $\begin{array}{l}\text { Translation } \\
\text { "soul(s)" }\end{array}$ \\
\hline b. & muntu (muntu) & 43 & antu (antu) & 21 & "person(s)" \\
\hline c. & mulêque (muleeke) & 35 & alêque (aleeke) & 12 & $\begin{array}{l}\text { "child(ren), } \\
\text { youngster(s)" }\end{array}$ \\
\hline d. & musundi (musundi) & 40 & - & & "virgin" \\
\hline e. & mufûnu (mufuипu) & 9 & $\begin{array}{l}\text { mifûnu } \\
\text { (mifuunu) }\end{array}$ & 20 & $\begin{array}{l}\text { "work(s), } \\
\text { action(s), merit(s)" }\end{array}$ \\
\hline & $\begin{array}{l}\text { muquembo } \\
\text { (mukembo) }\end{array}$ & 26 & - & & "glory" \\
\hline
\end{tabular}




\begin{tabular}{|c|c|c|c|c|}
\hline g. muquissi (mukissi) & 19 & aquissi (akissi) & 3 & "holy" \\
\hline h. mulongo (mulongo) & 21 & - & & "law, rule" \\
\hline mutîma (mutiima) & 18 & mitîma (mitiima) & 2 & "heart(s)" \\
\hline j. muânu (muaаnu) & 17 & miânu (miaanu) & 3 & $\begin{array}{l}\text { "manner(s), } \\
\text { way }(\mathrm{s}) \text { " }\end{array}$ \\
\hline k. mulongui (mulongi) & 15 & - & & "doctrine, sermon" \\
\hline $\begin{array}{l}\text { 1. mucangui (mu- } \\
\text { kangi) }\end{array}$ & 11 & - & & "savior" \\
\hline
\end{tabular}

The second-oldest Kikongo source that survived the ravages of time is a manuscript from 1652 by the Flemish Capuchin missionary Joris van Gheel, called the Vocabularium Latinum, Hispanicum, e Congense (Van Gheel 1652). The manuscript was drastically redrafted by the Belgian Jesuits Joseph van Wing and Constant Penders, who published it in the 20th century (Van Wing \& Penders 1928). Recent diachronic phylogenetic research confirms that the 1652 doculect is very closely related to the 1624 doculect, and thus also South Kikongo (De Schryver et al. 2013). In this dictionary, produced less than three decades after the publication of the catechism, the start of $m u$ - syncope may be observed (De Kind 2012). The syncopated $m u$ - prefix of classes 1 and 3 is noted as $m$ '- in the Vocabularium Congense. As shown in (15), three of the twelve most frequent cl. $1 / 2$ and $3 / 4$ nouns from the 1624 catechism, listed in (14), are unsystematically transcribed with $m^{\prime}$ - or $m u$ - in the Vocabularium Congense. The other nouns in (14) having a stem-initial oral consonant are always represented with the full $m u$ - prefix. The plural prefix of class 4 is always $m i$-, including when the singular prefix is reduced.

\begin{tabular}{llllll}
\multicolumn{3}{c}{ Freq. } & & Freq. & Translation \\
a. m'fúnú & 2 & vs. mufunu & 5 & "work, action, merit" \\
b. mqúissi & 1 & vs. múqúissi & 3 & "holy" \\
c. m'tima & 20 & vs. mutima & 2 & "heart"
\end{tabular}

As shown in (16), sixteen additional nouns were found which are sometimes attested with an $m^{\prime}$ - prefix.

\begin{tabular}{llllll}
\multicolumn{3}{c}{ Freq. } & & Freq. & Translation \\
a. m'cua & 75 & vs. & mucua & 44 & "owner, possessor of" \\
b. m'ti & 43 & vs. & $\begin{array}{l}\text { muti } \\
\text { c. }\end{array}$ & 5 & "tree" \\
c. m'canda & 5 & vs. & $\begin{array}{l}\text { mucanda } \\
\text { d. m'tu }\end{array}$ & 18 & "book; letter" \\
e. m'tinú & 8 & vs. & $\begin{array}{l}\text { mutu } \\
\text { es. }\end{array}$ & 5 & "head" \\
f. missinga & 1 & vs. & $\begin{array}{l}\text { mussinga } \\
\text { muçinga }\end{array}$ & 2 & "king" \\
& & & & "rope, string" & \\
g. m'zoqui & 2 & & & & "envy"
\end{tabular}




$\begin{array}{lll}\text { h. m’ssúa } & 2 \\ \text { i. } & \text { m'casa } & 1 \\ \text { j. } & \text { m’bhuami } & 1 \\ \text { k. m'cotami } & 1 \\ \text { l. } & \text { m'qúecambuaco } & 1 \\ \text { m. m'qúelúsilúco } & 1 \\ \text { n. } & \text { m'tangui } & 1 \\ \text { o. m'tani } & 1 \\ \text { p. m'tuecúnzi } & 1\end{array}$

"peace"
"wife; spouse"
"fool"
"sadness"
"abundance"
"without will"
"calculator"
"warrior"
"the capital of a column"

Most of the syncopated nouns in (16) occur only once or twice and mostly have no non-syncopated equivalent. The two most frequently occurring syncopated nouns in the Vocabularium Congense are micua (16a), which is very common in compound nouns, and m'ti (16b). Both still have non-syncopated attestations. This is also true for the three syncopated nouns in $(16 c-e)$, which are also frequent words.

Important to stress is the consistent notation of the syncopated $m u$-prefix as $m$ ' in the Vocabularium Congense. The apostrophe most likely signals the syllabicity of the nasal prefix. This is unlike the nasal prefix of classes 9 and 10, which is consistently written without an apostrophe, e.g. ngombe/ngombe (9/10) for Latin bos "ox, cow", or lucata/ncata $(11 / 10)^{2}$ for Latin capsa "box". As shown in (16), the syncopated $m$ '- prefix occurs in front of stem-initial consonants having different places of articulation: bilabial, coronal and velar. The invariable bilabial notation of the prefix no doubt reflects the fact that this nasal prefix was not homorganic yet. According to the three-stage model in Figure 1, the 1652 doculect represents the transition between Stage 1 (full prefix) and Stage 2 (syllabic bilabial nasal).

As observed by De Kind (2012:119), the process was possibly already more advanced in the 1650s than reflected in the Vocabularium Congense. This is at least suggested by the earliest Kikongo grammar, published in 1659 by Hyacintho Brusciotto à Vetralla, another Capuchin missionary (Doke 1935:97). This grammar was published only seven years after the drafting of the surviving Vocabularium Congense manuscript. Both linguistic works adopt exactly the same orthography. The following paragraph from the grammar's English translation, edited by Guinness (1882: 84, italics in the original), is highly relevant to the question of $m u$ - syncope:

2. In the case of the class pair 11/10, the number of the plural prefix is lower than that the singular, because the homorganic nasal prefix of class $10 \mathrm{~N}$ - is the plural of both singular class $9\left(N^{-}\right)$and $11(l u-)$. 
"All words, both nouns and verbs, having the letter $U$ for the second letter of the first syllable are so pronounced, that the $U$ is not heard except when another vowel follows it or the letter $\mathrm{N}$, as, Mubhobheri, advocate; mutima, conscience; Mutinu, king; are pronounced with a synalepha in the first syllable, thus, M'bhobheri, m'tima, m'tinu, and so in the plural, the letter I is not expressed, Mufunu mifunu, for the first $U$ is dropped in the singular, and in the plural, I."

Brusciotto clearly describes here the process of prefix syncope, erroneously labelled synalepha here, i.e. the fusion of two syllables into one in the pronunciation of two successive vowels of adjacent syllables (Vega 2010). He only speaks of the dropping of the prefix vowel, but does not mention any changes to which the nasal consonant would be subject and which would indicate homorganicity. He does seem to suggest, however, that prefix syncope had already been generalized to all nouns belonging to classes 1 and 3 and having a stem-initial oral consonant and that the process had already affected the mi- prefix of class 4 as well. Given that $m i$ - syncope is not yet attested at all in the Vocabularium Congense, and $m u$ - syncope only unsystematically, the description by Brusciotto might indicate that the process, once started, diffused rapidly through the lexicon. However, the fact that Brusciotto himself still consistently writes $m u$-indicates that this phonological change was still young and not consistently reflected yet in the common spelling of the time.

\subsection{8th-century West Kikongo (1770s)}

The actual diachronic West Kikongo sequence starts in the second half of the 18th century thanks to the pioneering linguistic legacy of the French missionaries who operated from 1766 to 1775 in the coastal area between Cabinda in the South and Loango (Pointe Noire) in the North, home to several smaller coastal kingdoms such as - from south to north - Ngoyo, Kakongo and Loango (Proyart 1776; Van Bulck 1954). Jean Joseph Descourvières, the missionary-in-chief from 1773 onwards, authored both a grammar and a dictionary of the local Kikongo variety of which only copies by himself and his confrères are still available in the archives of the Propaganda Fide in Rome, the British Library in London and the municipal library of Besançon (Van Bulck 1954). The KongoKing research group acquired digital copies of four of these historical documents: (a) Dictionnaire françois et congo (in London, from 1772), (b) Dictionnaire françois et congo (in Besançon, from 1773), (c) Dictionnaire congo et françois (in Besançon, from 1775) and (d) Essai d'une grammaire congo, suivant l'accent de Kakongo (in Besançon, from 1776). Diachronic phylogenetic research indicates that the Kikongo variety documented in the dictionary manuscripts is most closely related to present-day Kikongo varieties belonging to the West cluster (De Schryver et al. 2013). 
In the 1776 grammar manuscript, the allomorphy between the full prefixes of classes 1, 3 and 4 and their syncopated nasal is the same as it was in mid-17thcentury southern Kikongo and as it still is today everywhere else, i.e. full prefixes in front of stems beginning with a vowel or a non-syllabic nasal (i.e. NC cluster) and syncopated prefixes elsewhere. (See the supplementary material online for the relevant quotes from the grammar, in French.) Several Kikongo words cited in the 1776 grammar manuscript testify to this allomorphy, as shown in (17). The vowel in parentheses preceding most nouns is the so-called 'augment' or 'pre-prefix' (De Blois 1970), which is common in Bantu, but has only survived in a limited number of Kikongo varieties. Its functions can be manifold, such as indicating definiteness or specificity, and its presence is often syntactically conditioned (Katamba 2003: 107). Its exact use in West Kikongo still needs to be determined.

(u) mu-ntu
(u) m'ti
(u) m'kuku/(i) m'kuku
(u) mu-ndele/(i) mi-ndele
mu-ana
(u) mu-ila
(i) mi-oko
(u) m'samu

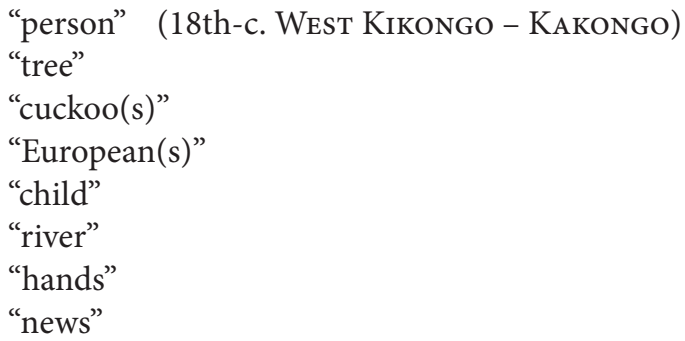

Drieghe (2014:110-111) shows that the data included in the dictionary manuscripts are consistent with the facts described in the grammar. The realization of $m u$ - syncope in 18th-century West Kikongo thus strongly resembles what we observed in the mid-17th-century South Kikongo Vocabularium Congense (Van Gheel 1652). The syncopated nasal had not become homorganic yet. Nevertheless, while the process had only started in mid-17th-century South Kikongo, it had reached completion in 18th-century West Kikongo. Another difference between the two historical Kikongo varieties is the behavior of the class 4 prefix mi-. While it unmistakably underwent syncope in 18th-century West Kikongo, its exact morphophonological realization in mid-17th-century South Kikongo is uncertain. It was consistently noted as a full prefix in the Vocabularium Congense (Van Gheel 1652), but according to Brusciotto's grammar (1659), it was already heard as a syncopated prefix (Guinness 1882: 84).

\subsection{8th-century South Kikongo (1779-1800)}

For the southernmost part of the South Kikongo cluster, we may have data for the end of the 18th century from an unlikely source: Bernardo Maria de Cannecattim's (1805) Collecção de Observações grammaticaes sobre a Lingua Bunda ou Angolense, which includes a 70-page lexicon in four columns, covering Portuguese, Latin, 
Kikongo and Kimbundu. De Cannecattim was an Italian Capuchin missionary who worked from Bengo (about $25 \mathrm{~km}$ north of Luanda) from 1779 to 1800 (Saccardo 1983:128). He had a good command of Kimbundu, the language he describes, but not of Kikongo. In the introduction to his lexicon, De Cannecattim (1805: 151) refers to an earlier quadrilingual (Kikongo-Portuguese-Latin-Italian) lexicon, supposedly from the hand of Brusciotto and published in Rome in 1650, but to this date it is not clear whether that early work was actually ever compiled, and if it was, whether De Cannecattim also saw it. It seems more likely that De Cannecattim had access to unpublished manuscripts of vocabularies which were available to and circulated amongst the Capuchin missionaries. Diachronic phylogenetic research indicates that the Kikongo variety described by De Cannecattim belongs to the southern cluster, and fits in between the mid-17th-century and the later 19th-century southern sources (De Schryver et al. 2013). Given the location from which De Cannecattim was operating, and the fact that he was comparing Kikongo with Kimbundu - spoken south of Kikongo - we assume that the Kikongo variety covered in De Cannecattim's work is one of the southernmost South Kikongo ones.

With regard to $m u$-/mi- syncope, De Cannecattim's Kikongo variety is similar to present-day Kitsotso (10), one of the southernmost Kikongo varieties. Both syncopated and non-syncopated class 1 and 3 nouns are found, as illustrated in (18).

Absence of mu-syncope
mucíma (3)
mucánda (3)
múti (3)
mubíngui/mibingui (3/4)
mofunu/mifunu (3/4)
muquémbo/miquémbo (3/4)

(late 18th-c. Southern South KiKongo)

Presence of $m u$ - syncope

$\begin{array}{lll}\text { "heart" } & \text { ntú (3) } & \text { "head" } \\ \text { "skin" } & \text { nquíla (3) } & \text { "tail" } \\ \text { "tree" } & \text { nsumúqui (1) "barber" } \\ \text { "lawyer(s)" } & \text { nquuéte (1) "carpenter" } \\ \text { "work(s)" } & & \\ \text { "glory/-ies" } & \end{array}$

\subsection{9th-century South Kikongo (1811, 1887-1895)}

For the early 19th century a single source provides data for Kikongo varieties in four different sub-groups of the KLC, i.e. Sigismund Wilhelm Koelle's landmark Polyglotta Africana (1854). This agent of the Church Missionary Society compares a vocabulary of about three hundred words and phrases in over a hundred distinct African languages, as recalled by liberated slaves from all over the continent found at sea and brought to Freetown, Sierra Leone. In addition to the vocabularies, Koelle provides detailed notes about the itineraries of his consultants and also attempts to locate the recorded languages on a map of the continent. Cross-comparing that map with the itineraries, as well as with subsequent research by Guthrie (1964) 
and Curtin \& Vansina (1964), it is possible to pinpoint the languages described as Western Kakongo and Kiyombe, Central Kisundi, Eastern Kintandu and Southern Kimboma. Each of these varieties will be looked at in separate sections. (All the examples from Koelle, here and further below, are included as supplementary material online.)

According to Hair (1963: 14), "Koelle began the regular collection of vocabularies in April 1850, and he appears, from a note in one of his letters, to have completed it by July 1852." Given that the consultant for 'Mimbóma', or thus Kimboma, had been in Sierra Leone for forty years, this would date the vocabulary he recollects to about 1811, if not earlier. Koelle's data shows that by the beginning of the 19th century, syncope had not only affected the class 1 and 3 $m u$ - prefix, but also that the class 4 prefix had already been reanalyzed as miN-. All these syncopated prefixes had also become homorganic.

In the approximately 150 years separating Brusciotto's (1659) South Kikongo grammar from the South Kikongo as spoken by Koelle's informant, i.e. the northernmost South Kikongo variety Kimboma, syncope had not only affected the class 1 and $3 m u$-prefix, as it had already started to do in mid-17th-century South Kikongo, but also the class $4 \mathrm{mi}$ - prefix. Moreover, since these syncopated prefixes had in the meanwhile become homorganic, they had reached the final step of the three-stage evolution.

As discussed by De Kind (2012:138-143), the same situation is observed in William Holman Bentley's late-19th-century linguistic work $(1887,1895)$ on Kikongo "as spoken at San Salvador, the ancient capital of the old Kongo empire", or central South Kikongo, except that the syncopated prefix of class 4 was not reanalyzed as miN-, as shown in (19). Bentley $(1887: 522,544)$ is probably the first to describe the syllabic nasal prefixes of classes 1, 3 and 4 as 'heavy nasals' as opposed to the non-syllabic 'light nasals' of noun classes 9 and 10, a term which was later adopted by Laman (1912:52) for Central Kikongo.

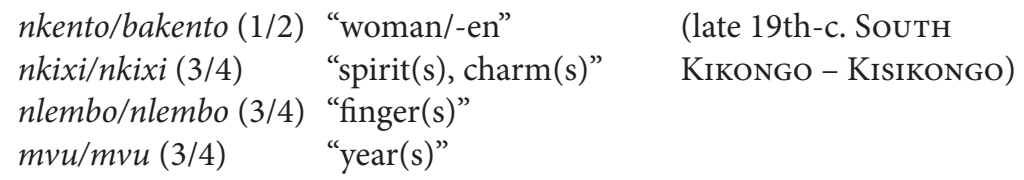

\subsection{9th-century West Kikongo (1818, 1821, 1888; 1833)}

We owe the earliest 19th-century West Kikongo data to the British Captain James Hingston Tuckey, who explored the Congo River and left a Kikongo lexicon with words from the 'Malemba' and 'Embomma' varieties in his travel account (Tuckey 1818:391-399). These glossonyms are actually toponyms referring to the trading ports of Malemba and Boma where he recorded these vocabularies. Malemba was the principal Atlantic port of the Kakongo kingdom. There he probably 
documented the same Kikongo variety as the French missionaries during the second half of the 18th century. Boma is an inland port on the Congo River, situated about $100 \mathrm{~km}$ upstream from its mouth. In the diachronic phylogenetic classification of Kikongo varieties, both Tuckey's doculects cluster with present-day West Kikongo varieties (De Schryver et al. 2013). Tuckey's data (included online) confirm that $m u$ - syncope had taken place in several West Kongo varieties, but are not coherent enough to make reliable judgments on the homorganicity of the resulting syllabic nasals.

Here, the data from Koelle's Polyglotta Africana may provide some extra evidence. Of the variety Koelle records as 'Kabénda', his consultant - who was last in the Congo 30 years before the interview, so about 1821 (which is the same period as Tuckey) - notes that it is spoken near Malémbo (Tuckey's Malemba). One again observes both homorganic and non-homorganic syncopated prefixes.

The next coastal West Kikongo data only appears towards the end of the 19th century, in the Grammaire de la langue fiote, dialecte du Kakongo by Carrie (1888), the later bishop and apostolic vicar of French Congo, who operated in the same region as his 18th-century French predecessors with whose work he does not seem to have been familiar. According to his grammar, the Kikongo variety spoken at the end of the 19th century in the vicinity of Landana, about $15 \mathrm{~km}$ to the north of Malemba, still had non-homorganic nasal prefixes for noun classes 1, 3 and 4. Carrie (1888) consistently writes $m$-, irrespective of the place of articulation of the stem-initial consonant. He sometimes writes it followed by an apostrophe, but not consistently. The syncopated prefix is sometimes given with its augment, but not always, as shown in (20) (Carrie 1888: $16-18,33)$.

mtinu $(1 / 2)$
mvika $(1 / 2,3 / 4)$ (pl. ba vika or $i$ mvika)
m’ḳento $(1 / 2,3 / 4)$ (pl. ba kento or $i$ mkento)
u mti $(3 / 4)(\mathrm{pl}$ i mti)
u mkanda (3/4) (pl. i mkanda)
u mkala (3/4) (pl. i mkala)

(late 19th-c. West KikONGo - KAKONGO)

"king(s)"

"slave(s)"

"woman/-en"

"tree(s)"

"hide(s)"

"furrow(s)"

Carrie clearly distinguishes the nasal prefixes of classes 3 and 4 from those of classes 9 and 10 (see the supplementary material online for the relevant quote, in French).

Carrie (1888: 33) also highlights an important dialectal difference between the Kakongo variety he describes and the neighboring Loango variety to the north regarding the homorganicity of the syncopated nasal prefixes: "Au Loango on dit $n t i$ au lieu de $m t i$, et dès lors l' $n$ passe à l'adjectif. EX.: nti nḳo." ("In Loango, one says $n t i$ instead of $m t i$, and thenceforth the $n$ also appears on the adjective. E.g.: nti nko."). While the Kakongo variety would not have evolved in this respect since 
the times of Descourvières, the variety spoken in Loango did develop homorganic nasal prefixes in classes 1, 3 and 4. Carrie (1888: 32) identifies the speakers of the variety spoken in Loango as Bavili. He categorizes the speakers of his Kakongo variety as Bakoke or Bakoce. Cikoci is one of the seven current-day Kikongo varieties of Cabinda (Futi 2012:15). As discussed above, syncopated nasal prefixes for classes 1 and 3 are homorganic in present-day Civili (4), but not in Cisundi (2). The late 19th-century dialectal divergence regarding $m u$ - syncope is also confirmed by Derouet's (1896) dictionary of the Loango variety and an anonymous dictionary of the Kakongo variety from around 1890 of which Carrie was probably one of the main compilers (Anonymous 1890?).

In sum, towards the end of the 19th century, the West Kikongo variety spoken at Landana in current-day Cabinda was situated at step 2 of the three-stage evolution presented in Figure 1, as its 18th-century predecessor was and present-day Cisundi (2) from the same area still is. The variety spoken in neighboring Loango in the vicinity of present-day Pointe Noire, in the Republic of the Congo, had already reached the final stage, which can also be observed today in West Kongo varieties from the same region, such as Civili (4).

Still within the Western sub-group, but now inland, Koelle also lists data for 'Nyómbe', dating back to about 1833. From Koelle's data one recognizes the present-day situation for Kiyombe, i.e. Stage 3.

\subsection{9th-century Central Kikongo (1842; 1887-1888)}

The earliest Kikongo data for the central sub-group, dating back to 1842, begins with Koelle's 'Basúunde'. The consultant informs us that he was kidnapped by the 'Bayómbe' at the age of 23, and that his variety is spoken to the east of 'Bambóma' and to the west of 'Mundóngo'. This places his variety right in between West, South and East. For this variety, Kisundi, it may be concluded that Stage 3 was reached, with a reanalysis for class 4 .

While Bentley undertook missionary linguistics in the southern part of the KLC, around the same time Nils Westlind of the Swedish Missionary Society did pioneering linguistic research on Kimanyanga, at the Mukimbungu mission in the center of the Lower Congo Province of today's DRC. He left us with the earliest extensive language data from this part of the KLC (Westlind 1887, 1888). As shown in (21), his data indicate that by that time $m u$-syncope had also reached the final stage of the three-stage evolution in this Central Kikongo variety, and that the class 4 prefix had also been reanalyzed as miN- (Westlind 1888: 39, 41-42).

$$
\begin{aligned}
& \text { nkento/bakento }(1 / 2) \\
& \text { nleke/baleke }(1 / 2) \\
& \text { ntekolo/batekolo }(1 / 2)
\end{aligned}
$$

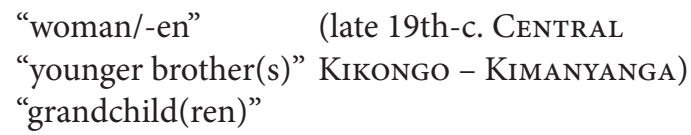




$\begin{array}{ll}\text { nti/minti (3/4) } & \text { "tree(s)" } \\ \text { nsakasu/minsakasu (3/4) } & \text { "bellow(s)" } \\ \text { nkabi/minkabi (3/4) } & \text { "donor(s)" }\end{array}$

\subsection{9th-20th-century East Kikongo $(1839,1909)$}

The diachronic linguistic sequence in the East cluster of the KLC again starts with Koelle's Polyglotta Africana, in which 'Musentáándu', i.e. Kintandu, is the only early source for any Eastern variety, dating back to 1839. This data again indicates that Stage 3 had been reached, with a reanalysis for class 4 . However, the reanalysis of class 4 for this region is not seen in the early 20th-century dictionary of the Jesuit missionary René Butaye (1909). As shown in (22), $m u$-/mi- syncope is complete in early 20th-century East Kikongo, with the plural prefix of class 4 a syllabic homorganic nasal.

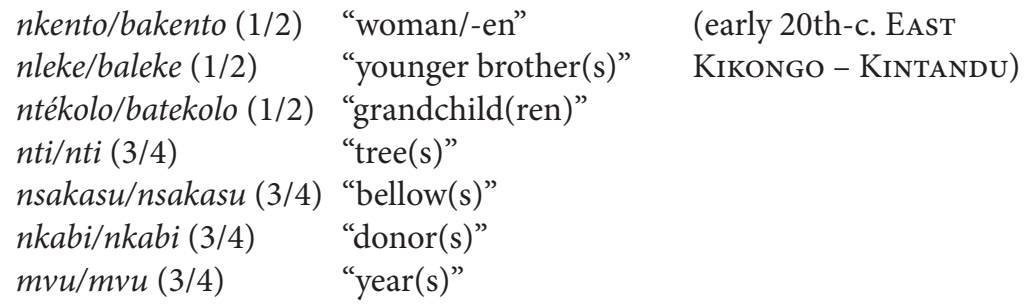

With regard to $m u$-/mi- syncope, the data from Butaye's dictionary do not differ from the Kintandu data in Daeleman (1983), collected in the same part of the KLC.

\subsection{Diachronic evolution of $m u$-/mi-syncope}

The three-stage evolution of $m u$ - syncope postulated on the basis of synchronic micro-variation within the KLC has now been corroborated by the diachronic data just presented. As displayed in Figure 2, the actual evolution of $m u$ - syncope within the KLC corresponds with a real time gradient. Stage 1 coincides with the oldest available South Kikongo data from 1624, while the transition from Stage 1 to Stage 2 is retrievable from slightly more recent South Kikongo data from 1652. The full achievement of Stage 2 is then observed in West Kikongo data from the 1770s. Finally, the earliest available evidence for Stage 3 is not older than the early 19th century. ${ }^{3}$

3. Weber (1924:143) was probably the first to hint at this evolution when discussing the different forms under which the word for "king" appears in the historical sources on the Kongo, i.e. mutinu $>$ mtinu $>$ ntinu. 


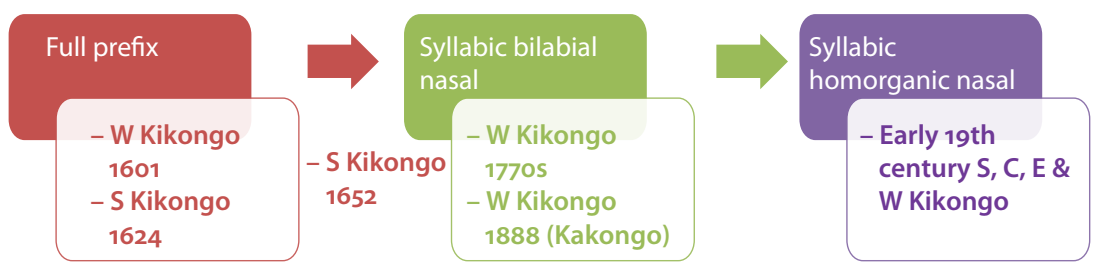

Figure 2. Three-stage evolution of $m u$-/mi- reduction corroborated by diachronic data

Considered in this way, the diachronic data seem to suggest that this innovation started in the southern part of the KLC during the 17th century and subsequently spread to other dialect zones, the earliest evidence for this diffusion stemming from 18th-century West Kikongo. However, the diachronic data remain fragmentary. In order to be sure that this change was really initiated in 17th-century South Kikongo spoken at the heartland of the Kongo kingdom, we would need 17th-century data from the other dialect clusters, especially from West Kikongo, and also 18th-century data from East and Central Kikongo, which does not exist to the best of our knowledge. In the present section, however, we present further empirical evidence for the way the innovation evolved within South Kikongo, and in $\$ 6$ we will present indirect linguistic evidence that strongly suggests that $m u-/$ $m i$ - syncope did indeed originate in the southern part of the KLC.

So far, the evidence for prefix syncope in classes 1 and 3 in South Kikongo is as follows: there is no evidence for it in the 1624 catechism (step 1), it starts to appear in Van Gheel's 1652 Vocabularium Congense (transition from step 1 to step 2), and Brusciotto's grammar indicates that step 2 was reached by 1659 . Thanks to Koelle's data, we also know that the process for central South Kikongo must have been finalized before ca. 1811 (step 3). While it is clear that sound changes do not happen overnight, it would still be desirable to be able to narrow down the time frame during which the transition from step 2 to step 3 occurred for central South Kikongo. At this point, that time frame stands at about 150 years. If it were possible to narrow it down, the sequencing of all subsequent sound changes, both within the South Kikongo subgroup (for the other noun classes) and for the other Kikongo subgroups (starting with classes 1 and 3, and onwards for the other classes), could be established. Given that we have already exhausted all the traditional linguistic resources (textbooks, wordlists, dictionaries, grammars), we now need to mine any historical documents in which South Kikongo words may have been mentioned. This is exactly what was done for a number of sample words, an example of which is shown in Table 1 (with more examples as supplementary material online). Date-stamped evidence is given for each of the three steps, and/or the transitions between them. This exercise shows that syncope in classes 1 and 3 in South Kikongo was likely completed before the end of the 17 th century. 
Table 1. South Kikongo word for "king(s)" (cl. 1/2)

\begin{tabular}{|c|c|c|c|c|}
\hline Phase & Kikongo & Year & Source & Reference \\
\hline 1 & mutino & 1622 & $\begin{array}{l}\text { A report written in } \\
\text { Portuguese by the Canon of } \\
\text { San Salvador, André Cordeiro } \\
\text { (arrived in Congo in 1610), to } \\
\text { the Jesuits in Luanda. [fol. } 174 \\
\text { r. \& fol. } 174 \text { v.] }\end{array}$ & (Jadin 1968:384, 386) \\
\hline 1 & mútinú/mitinú & 1624 & Catechism & $\begin{array}{l}\text { (Bontinck \& Ndembe } \\
\text { Nsasi 1978) }\end{array}$ \\
\hline $1 \Rightarrow 2$ & $\begin{array}{l}\text { mutinú }(2 x) \\
\Rightarrow \\
\text { m'tinú }(8 x)\end{array}$ & 1652 & Vocabularium Congense & (Van Gheel 1652) \\
\hline 2 & m'tinu & 1659 & Brusciotto's Kikongo grammar & (Guinness 1882: 84) \\
\hline 3 & ntinu & 1698 & $\begin{array}{l}\text { A report written in Italian } \\
\text { by the Capuchin Luca da } \\
\text { Caltanisetta (in Congo } \\
\text { 1690-1701). [fol. } 59 \text { r.] }\end{array}$ & (Bontinck 1970: 128) \\
\hline
\end{tabular}

At the same time, i.e. the second half of the mid-17th century, $m u-/ m i-$ syncope had not yet begun in other parts of the KLC. For example, in a travel account published in 1692, the Capuchin Girolamo Merolla da Sorrento, who had disembarked in Luanda in 1683, uses - in a section on the description of the people living in the city of Luanda - the words mocchamas and muccamas to refer to "an African waiting maid" (Merolla da Sorrento 1692: 378, 388). One notices the full form of this class 1 noun. After Luanda, he moved on to the coastal Soyo in the north, where he did missionary work from 1683 to 1688 (and later again from 1693 until his death in 1697). In a section on the way Africans feast, he uses the word moringo for "flask" (p. 448). In the index to his work, finally, he lists molecches as "a generic name to refer to an African" (p. 462). One again notices the full form for these class 1 and 3 nouns.

The fact that certain South Kikongo varieties, such as the one documented by De Cannecattim (1805; cf. \$4.4), did not systematically apply $m u$-/mi- syncope at the end of the 18th century, indicates that this innovation did not spread evenly through the KLC, not even within those varieties closely related to the central South Kikongo variety where the process started.

\section{Prefix reduction in other noun classes}

Nasal prefix syncope as observed in classes 1, 3 and 4 and discussed in $\$ \$ 3$ and 4 is the most widespread - but not the only - type of prefix reduction observed in Kikongo. The existence of phonologically reduced prefixes is a much wider 
phenomenon in Kikongo (Bittremieux 1943-44). As we argue in this section, these different types of prefix reduction are probably historically connected and share a common geographical origin.

\subsection{A synchronic description}

The reduction of noun prefixes of classes other than 1, 3 and 4 is especially regular in South Kikongo. In Kisikongo, for instance, the noun prefixes of classes 5, 7, 8 and 15 undergo a reduction that is even more extreme: they have become zero (De Kind 2012:163-164, 165-166, 170). The phonological conditioning of this reduction is identical to the one triggering $m u$ - $m i$ - syncope: full prefix when the noun stem starts with a vowel or a NC cluster, null prefix when it starts with an oral consonant. This allomorphy is illustrated in (23) with Kisikongo data from Ndonga Mfuwa (1995). An exception to class $7 \mathrm{ki}$ - reduction occurs in derived nouns, which generally maintain their prefixes if their stems begin with oral consonants (Bentley 1887: 296-301, 534). An exception to class $15 \mathrm{ku}$-reduction is observed with the monosyllabic noun stem kú-tù/má-tù “ear(s)” (Ndonga Mfuwa 1995: 145, 191).

(23) Prefix reduction in 20th-century Kisikongo (De Kind 2012:164-171).

a. $\underline{\text { Class } 5}$

$\begin{array}{lll}\text { Ø/_C } & \begin{array}{l}\text { kónkò } \\ \text { sékwà }\end{array} & \begin{array}{l}\text { "grasshopper" } \\ \text { dinkóndò }\end{array} \\ \text { di-/_NC } & \begin{array}{l}\text { "bassava flour" } \\ \text { dímè } \\ \text { dyámbà } \\ \text { dyáki }\end{array} & \text { "dew" } \\ & \text { "hemp" } \\ & \text { "egg" }\end{array}$

b. Classes 7/8

$\emptyset / \_C$

fúlù/fúlù

"place(s)"

lékwà/lékwà

"thing(s)"

ki-/_NC

kimvúminà

"mother's milk"

kìnsángà

"tear"

$\mathrm{ky}-/$ _ V

kyámvù/yámvù

"bridge(s)"

yi-/_NC

yimpúkù-mpúkù

"small rats"

yinsùkú-nsúsù

"small chickens"

c. Class 15

$\begin{array}{lll}\text { Ø/_C } & \text { lúkà } & \text { "to vomit" } \\ & \text { sálà } & \text { "to work" } \\ & \text { dyà } & \text { "to eat; meal" } \\ & \text { kwéndà } & \text { "to go, to walk" } \\ \text { kw-/__ } \mathrm{V}_{[-\mathrm{u}]} & \text { kwìzà } & \text { "to come" } \\ \mathrm{ku}-/ \_\mathrm{u} & \text { kùúlù } & \text { "leg" }\end{array}$


Class 5 will not be considered further here, since Kikongo-specific reduction interferes with a more Bantu-wide allomorphy involving its noun prefix and augment (Kamba Muzenga 1988; Lafon 1994; Ngunga 1997). As for the reduction of the other noun class prefixes, these innovations are clearly less widespread than $m u$-/mi- syncope, as shown in (24). In $\$ 3$ we saw that only the North Kikongo cluster (except for Cilaadi) has not been affected by $m u$ - syncope, and only three more varieties, the southernmost South Kikongo variety Dihungu, and the two northernmost West Kikongo varieties, i.e. Civili (Gabon) and Kiyombi, have also not undergone mi- syncope. Conversely, as listed in (24), the reduction of class 7 and 15 prefixes is absent from or only irregularly attested in several more Kikongo varieties, while class 8 prefix reduction is only attested in a small minority of varieties. The variable distribution of these related innovations suggests that they happened successively, started at different points in time and therefore had an unequal spatial impact. The varieties in (24) are once again clustered according to the phylogenetic subgroups identified by De Schryver et al. (2013).

(24) The distribution of class prefix reduction.

\begin{tabular}{|c|c|c|c|c|c|c|c|}
\hline & & $\mathrm{NP}_{1 / 3}$ & $\mathrm{NP}_{4}$ & $\mathrm{NP}_{7}$ & $\mathrm{NP}_{8}$ & $\mathrm{NP}_{15}$ & \\
\hline \multirow[t]{6}{*}{ South } & Kisikongo & $\checkmark$ & $\checkmark$ & $\checkmark$ & $\checkmark$ & $\checkmark$ & (Ndonga Mfuwa 1995) \\
\hline & Kimboma & $\checkmark$ & $\checkmark$ & $\checkmark$ & $x$ & $\checkmark$ & (Kisilu Meso 2001) \\
\hline & Kisolongo & $\checkmark$ & $\checkmark$ & $\checkmark$ & $x$ & $\checkmark$ & $\begin{array}{l}\text { (Tavares 1915, KK fieldwork } \\
\text { 2012) }\end{array}$ \\
\hline & Kizombo & $\checkmark$ & $\checkmark$ & $\checkmark$ & $\checkmark$ & $\checkmark$ & (Carter 1970) \\
\hline & Kitsotso & $\sqrt{ } / X^{4}$ & $\sqrt{ } / x$ & $x$ & $x$ & $x$ & (Baka 1992) \\
\hline & Dihungu & $\checkmark$ & $x$ & $x$ & $x$ & $x$ & (Atkins 1954) \\
\hline \multirow[t]{2}{*}{ Central } & Kindibu & $\checkmark$ & $\checkmark$ & $\checkmark$ & $x$ & $\checkmark$ & (Coene 1960) \\
\hline & Kimanyanga & $\checkmark$ & $\checkmark$ & $\checkmark$ & $\checkmark / x$ & $\checkmark$ & (Laman 1912; Makokila 2012) \\
\hline \multirow[t]{4}{*}{ East } & Kintandu & $\checkmark$ & $\checkmark$ & $\checkmark / X$ & $x$ & $x$ & $\begin{array}{l}\text { (Butaye 1910; Daeleman } \\
\text { 1966) }\end{array}$ \\
\hline & Kimbata & $\checkmark$ & $\checkmark$ & $\checkmark / X$ & $x$ & $x$ & (KK fieldwork 2012) \\
\hline & Kimbeko & $\checkmark$ & $\checkmark$ & $x$ & $x$ & $x$ & (KK fieldwork 2012) \\
\hline & Kinkanu & $\checkmark$ & $\checkmark$ & $x$ & $x$ & $x$ & (KK fieldwork 2012) \\
\hline \multirow[t]{2}{*}{ West } & Kiyombi & $\checkmark$ & $x$ & $x$ & $x$ & $x$ & (Mabiala 1992, 1999) \\
\hline & Civili (Gb) & $\checkmark$ & $x$ & $x$ & $x$ & $x$ & $\begin{array}{l}\text { (Ndinga-Koumba-Binza } \\
\text { 2000) }\end{array}$ \\
\hline
\end{tabular}

(Continued)

4. $S / X$ indicates that syncope and reduction do not apply systematically. 
The distribution of class prefix reduction (Continued)

\begin{tabular}{|c|c|c|c|c|c|c|c|}
\hline & & $\mathrm{NP}_{1 / 3}$ & $\mathrm{NP}_{4}$ & $\mathrm{NP}_{7}$ & $\mathrm{NP}_{8}$ & $\mathrm{NP}_{15}$ & \\
\hline & Cisundi & $\checkmark$ & $\checkmark$ & $x$ & $x$ & $x$ & (Futi 2012) \\
\hline & Iwoyo & $\checkmark$ & $\checkmark$ & $x$ & $x$ & $x$ & (Mingas 1994) \\
\hline & Kiyombe & $\checkmark$ & $\checkmark$ & $S / x$ & $x$ & $\checkmark$ & $\begin{array}{l}\text { (De Clercq 1921; } \\
\text { De Grauwe 2009) }\end{array}$ \\
\hline & Kizobe & $\checkmark$ & $\checkmark$ & $\checkmark / X$ & $x$ & $x$ & (KK fieldwork 2012) \\
\hline & Cilinji & $\checkmark$ & $\checkmark$ & $x$ & $x$ & $x$ & (KK fieldwork 2012) \\
\hline & Ciwoyo & $\checkmark$ & $\checkmark$ & $\checkmark$ & $\checkmark$ & $\checkmark$ & (KK fieldwork 2012) \\
\hline & Cizali & $\checkmark$ & $\checkmark$ & $\checkmark$ & $x$ & $\checkmark$ & (KK fieldwork 2012) \\
\hline & Cimbala & $\checkmark$ & $\checkmark$ & $\checkmark$ & $x$ & $\checkmark$ & (KK fieldwork 2012) \\
\hline \multirow[t]{7}{*}{ North } & Cilaadi & $\checkmark / x$ & $\checkmark / x$ & $\checkmark$ & $x$ & $\checkmark$ & (Mabiala 1999) \\
\hline & Kibembe & $x$ & $x$ & $x$ & $x$ & $x$ & (Nsayi 1984) \\
\hline & Kihangala & $x$ & $x$ & $x$ & $x$ & $x$ & (Mabiala 1999) \\
\hline & Kikamba & $x$ & $x$ & $x$ & $x$ & $x$ & (Bouka 1989) \\
\hline & Kidondo & $x$ & $x$ & $x$ & $x$ & $x$ & (Mfoutou 1985) \\
\hline & Kikunyi & $x$ & $x$ & $x$ & $x$ & $x$ & $\begin{array}{l}\text { (Birgit Ricquier fieldwork } \\
\text { 2010) }\end{array}$ \\
\hline & Kisundi & $x$ & $x$ & $x$ & $x$ & $x$ & $\begin{array}{l}\text { (N’landu Kitambika 1994; } \\
\text { Mabiala 1999) }\end{array}$ \\
\hline
\end{tabular}

As the overview in (24) shows, the distributions of noun class 7 and 15 prefix reduction are relatively parallel to one another and coincide to a great extent with that of $m u$-/mi-syncope. However, they are absent from several varieties where the latter does occur, which suggests that $k i-$ or $c i-(c l .7)$ and $k u-(c l .15)$ reduction started later or spread more slowly. Both prefixes are only systematically dropped in central South Kikongo and Central Kikongo, as well as Cilaadi in the North Kikongo cluster. Unlike $m u$-/mi-syncope, it is not systematic in the East Kikongo cluster and totally absent from the northernmost West Kikongo varieties. In the extreme South of the KLC, i.e. in varieties such as Kitsotso and Dihungu, it is also completely missing.

In East Kikongo, infinitives preserve their class $15 \mathrm{ku}$-prefix, and while the reduction of the class $7 \mathrm{ki}$ - prefix has not been observed in the easternmost Kimbeko and Kinkanu, it is optional in the westernmost Kimbata and Kintandu, as Butaye (1910:18) already observed in the early 20th century (see the supplementary material online for the relevant quote, in French).

In West Kikongo, the reduction of the $k i$ - or $c i$ - prefix of class 7 is only regularly observed in the southernmost varieties, such as Ciwoyo, Cizali, Cimbala, Kizobe and Kiyombe, even if it is not fully systematic in the latter two. De Grauwe's 
(2009) Kiyombe lexicon, for instance, contains several nouns where the ki- prefix precedes a stem-initial non-aspirated oral consonant. The reduction of the $k u$-prefix of class 15 is observed in the same varieties except Kizobe. In Ciwoyo, as shown in (25), the ci- prefix of class 7 no longer appears as a surface morpheme before stems with an initial oral consonant, but is transphonologized as the palatalization of the stem-initial consonant, as opposed to the plural form where the $b i$ - prefix (of cl. 8) drops without any effect on the following consonant. The same sound shift is observed in class 5 , though the class 6 plural prefix ma- is maintained.

$\begin{array}{ll}\text { tyeba/teba }(7 / 8) & \text { "banana(s)" } \\ \text { syalu/salu }(7 / 8) & \text { "work(s)" } \\ \text { lyumbu/lumbu (7/8) } & \text { "day(s)" } \\ \text { kyalu/makalu (5/6) } & \text { "car(s)" }\end{array}$

(Ciwoyo)

(KK fieldwork 2012)

The reduction of the class 8 plural prefix $(b) i$-is less widespread, indicating that this innovation started even later or spread even more slowly. It is only fully regular in the South Kikongo varieties Kisikongo and Kizombo, and in the Western variety Ciwoyo. It is even absent from the central South Kikongo varieties Kisolongo and Kimboma, which suggests that this innovation only started once South Kikongo had already reached a considerable degree of internal diversification. It is entirely absent from the North and East Kikongo clusters, and also from the West Kikongo cluster with the exception of Ciwoyo. In the Central Kikongo variety Kimanyanga, the plural prefix $b i$ - seems to be optional before stem-initial consonants. Makokila (2012:95) presents the examples in (26), while Laman (1912:67) lists several prefix-less class 8 forms, but notes that "[t]he plural prefix is used in case there is no modifying word which indicates the plural." The markedness of the plural is probably the reason why the reduction of the plural prefixes $m i$ - and $b i$-is less common than the reduction of their respective singular prefixes $m u$ - and $k i$ - or $c i$-, even if $m i$ - is more commonly syncopated than $b i-$.

$\begin{array}{ll}\text { koonko/bikoonko (7/8) } & \text { "coin(s)" } \\ \text { funda/bifunda (7/8) } & \text { "package(s)" } \\ \text { taanzí/bitaanzí(7/8) } & \text { "machete(s)" } \\ \text { zizi/bizizi (7/8) } & \text { "face(s)" }\end{array}$

(KIMANYANGA)

\subsection{A diachronic description}

The present-day distribution of the different kinds of prefix reduction, all conditioned by the same phonological contexts, suggests that this innovation started with the nasal-initial prefixes, i.e. first $m u$ - and then $m i$-, and subsequently affected other prefixes, i.e. $k i$ - or $c i$ - and $k u$ - and only to a lesser extent or in a later stage $b i$. The diachronic data which we present in this section corroborate this scenario. 
In 17th-century South Kikongo, there is no trace yet of the reduction of the class 7,8 and 15 prefixes. In the 1624 catechism, they are systematically represented as $q u i-(=k i-), i$ - and $c u$ - $(=k u-)$, as illustrated in (27). The class 8 prefix $i$ - regularly corresponds to $b i$ - in other Kikongo varieties, since ${ }^{\star} b>\varnothing$ is a regular sound shift in South Kikongo when ${ }^{*} b$ is not preceded by a nasal or followed by a closed vowel (De Kind 2012).

a. quilumbu quiatâtu

ki-lumbu ki-a tatu

(early 17th-c. South Kikongo)

$\mathrm{NP}_{7}$-day $\mathrm{PC}_{7}$-CON three

"the third day"

(Bontinck \& Ndembe Nsasi 1978: 107)

b. ilumbu yaasantu

i-lumbu i-a santu

$\mathrm{NP}_{8}$-day $\mathrm{PC}_{8}$-CON holy

"holy days"

(Bontinck \& Ndembe Nsasi 1978: 139)

c. Cufunguna cumôci cuanfundu zanene ...

ku-fung-ul-a ku-mosi ku-a N-fundu

$\mathrm{NP}_{15}$-open-SEP-FV $\mathrm{NP}_{15}$-one $\mathrm{PC}_{15}$-CON $\mathrm{NP}_{10}$-secret

zi-a nene

$\mathrm{PC}_{10}$-CON greatness

"A revelation of the great mysteries ..." (Bontinck \& Ndembe Nsasi 1978: 109)

As the data in (28) from Van Gheel's 1652 Vocabularium Congense and in (29) from Brusciotto's 1659 grammar testify to, this situation had not changed three decades later, in contrast to $m u$ - syncope, which had already started by that time (De Kind 2012: 125-134).

$\begin{array}{ll}\text { quicunda/icunda (7/8) } & \text { "seat(s), sideboard(s)" } \\ \text { quibatú/ibatú (7/8) } & \text { "abbreviation(s)" } \\ \text { quilezo/ilezo (7/8) } & \text { "sloth(s)" } \\ \text { quisanzi/isanzi (7/8) } & \text { "basket(s)" } \\ \text { cúúúta (15) } & \text { "to dress" } \\ \text { cúfúa (15) } & \text { "to die" } \\ \text { cudia (15) } & \text { "to eat" }\end{array}$

(mid-17th-c. South

KiKONGO)

a. Quifu quia quiculu

ki-fu ki-a ki-kulu

(mid-17th-c. South Kikongo)

$\mathrm{NP}_{7}$-habit $\mathrm{PC}_{7}$-CON $\quad \mathrm{NP}_{7}$-old

"An old habit"

(Guinness 1882: 6)

b. eilumbu ey

e i-lumbu e-i

$\mathrm{AUG}_{8} \quad \mathrm{NP}_{8}$-day PROX.DEM-PC 8

"these days"

(Guinness 1882: 6) 


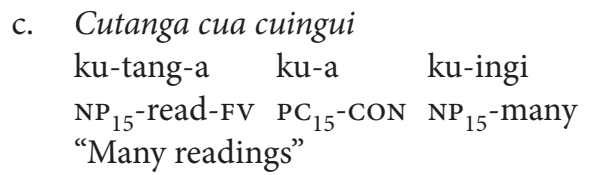

(Guinness 1882: 9-10)

The first southern traces of $k i$ - reduction are found, although not consistently, in the South Kikongo variety included in the lexicon attached to De Cannecattim's (1805: 149-218) Kimbundu grammar, as illustrated in (30).

\begin{tabular}{|c|c|c|c|}
\hline \multirow{2}{*}{\multicolumn{2}{|c|}{ Absence of $k i$ - reduction }} & \multirow{2}{*}{\multicolumn{2}{|c|}{ Presence of $k i$ - reduction }} \\
\hline & & & \\
\hline quivúmu/ivúmu (7/8) & "belly/-ies" & vútu (7) & "relative" \\
\hline quilúmbu/ilúmbu (7/8) & "day(s)" & sálu (7) & "work" \\
\hline quiándu/iándu (7/8) & "chair(s); bed(s)" & kálu (7) & “comb" \\
\hline quinína (7) & "dance" & & \\
\hline quibénzu/ibénzu (7/8) & "clear(s)" & & \\
\hline quicínsu/icínsu (7/8) & "signal(s)" & & \\
\hline
\end{tabular}

The first clear evidence for class 7 reduction for all Kikongo regions except for the North may be found in Koelle's lists from the early 19th century. The limited data (shown as supplementary material online) seems to indicate that class 7 reduction was an innovation in the South, West, Center and East by then. The data also suggest that the class 8 prefix had not been syncopated anywhere. Unfortunately, Koelle does not contain data for class 15.

By the end of the same century, however, $k i$-, yi- and $k u$-reduction are reported for Kisikongo by Bentley (1887: 547), whose 6th class corresponds to class pair 7/8:

"The 6th class are those nouns which at one time bore the prefix ki, sing., i or yi, $p l$., as the nouns of the previous class, but having neither a vowel nor light nasal as the initial of their stem, they have dropped their prefixes both in the singular and the plural."

This process must have started before the 1770 s, since by that time the innovation is already reported in the West Kikongo variety as spoken in Kakongo and documented by Descourvières and his confrères. (See the supplementary material online for the relevant quotes from their grammar manuscript, in French.) At the end of the 18th century, not only the $m u$ - prefix, but also the $k i$ - and $k u$ - prefixes had thus undergone reduction in the West Kikongo variety of Kakongo, but not the $b i$ - prefix, a situation which is confirmed by the data provided by the 18 thcentury dictionary manuscripts. This indicates that by that time an important divide must already have existed within the West Kikongo cluster, i.e. between those varieties which reduce the $k i$ - and $k u$ - prefixes, like today's southernmost West Kikongo varieties, and those which do not, like today's northernmost West Kikongo varieties. This dialectal split is confirmed one century later when 
Carrie (1888: 22; see supplementary material online, in French) compares the variety spoken by the Bakoce (Kakongo) with that of the Bavili (Loango).

The elision of the vowel $i$ reported for the $k i$ - prefix in 18th-century West Kikongo and for the bi- prefix in both 18th- and 19th-century West Kikongo suggests that the total reduction of these prefixes also happened via an intermediate step of vowel elision, as was the case with $m u$-/mi- syncope. Within South Kikongo, this intermediate step possibly went unnoticed due to the documentation gap between the mid-17th century and the early 19th century.

\section{Prefix reduction as the result of dialect diffusion}

The diachronic evidence presented so far indicates that the phonological reduction of noun class prefixes in Kikongo started in the course of the 17th century. The prefix reduction first attested in our diachronic corpus is nasal prefix syncope, namely in Van Gheel's South Kikongo dictionary of 1652. Hence, the noun prefixes of classes 1, 3 and 4, all beginning with a nasal, were probably first affected. From a cross-linguistic point of view, this is in line with expectations, since this sound change is widespread in Bantu. Having a straightforward articulatory motivation, it took place recurrently and independently in different related Bantu languages. In contrast to other Bantu languages, prefix reduction did not remain limited to those prefixes, but also affected other noun class prefixes not having a nasal, especially those of classes 7, 8 and 15. It is not entirely clear whether the reduction of the $k i$-, $b i$ - and $k u$ - prefixes is to be seen as an extension of nasal prefix syncope to other noun classes or as an independent process. The fact that it takes place in the same phonetic environments, i.e. before oral consonants, suggests that the two types of prefix reduction are interrelated. The fact that in classes 7, 8 and 15, it is not only the vowel that is syncopated, but rather the whole prefix suggests the opposite. However, the oral stops $/ \mathrm{k} /$ and $/ \mathrm{b} /$ are more difficult to maintain as syllable nucleus once vowel syncope took place, which makes total prefix deletion more likely. The notation of these reduced prefixes as $k^{\prime}$ and $b^{\prime}$ in the late 18thcentury sources for the variety spoken in Kakongo points to vowel syncope as an intermediate step. In sum, all evidence converges to suggest that nasal prefix syncope in classes 1, 3 and 4 and prefix reduction in classes 7,8 and 15 are part of a larger set of historically related innovations. This process started out with the common Bantu nasal prefix syncope but was subsequently extended to other noun prefixes.

This extension to other noun classes makes nasal prefix syncope as it takes place in Kikongo in distinct comparison to other Bantu languages. This is one of the reasons why polygenesis is not the most parsimonious explanation to account 
for nasal prefix syncope within the KLC. Given its widespread distribution in Bantu naturally resulting from its articulatory motivation, Nurse \& Hinnebusch (1993:185) consider nasal prefix syncope to be "of minimal value in subgrouping", since it represents "instances of parallel yet independent change." While this assumption certainly holds on a macro-level, we do not believe that nasal prefix syncope constitutes convergent evolution on the micro-level of the KLC. First of all, the fact that we are able to locate its starting point in time and space and that we can show that it first affected prefixes with a nasal and was later extended to other noun prefixes suggests that this innovation neither randomly spread through the KLC nor resulted from convergent evolution. Secondly, the present-day distribution of nasal prefix syncope within the KLC is historically significant. The change is not observed in more distantly-related neighboring language groups, such as Kimbundu in the South or Teke in the North (Bell 1972), nor in Kisuku in the East, as shown in (13) above. It is also unevenly spread within the KLC itself, though not in a geographically random manner. As shown in (8), its distribution crosscuts the preliminary phylogenetic clades we established within the KLC.

If we take the most widespread form of prefix reduction, the syncope of the $m u$ - prefix of classes 1 and 3, we observe that it only fully affected the South, East and Central subgroups, although the southern outlier Dihungu represents an incomplete achievement, i.e. the non-homorganic nasal. In the North and West subgroups, not all members share nasal prefix syncope. Within North Kikongo, only Cilaadi manifests it, though inconsistently. Within West Kikongo, most southernmost core members attest it, although Cisundi also still has the nonhomorganic nasal. However, the northernmost members spoken in Gabon did not undergo it (cf. 12). If the KLC indeed constitutes a distinct historical unit within the wider region (De Schryver et al. 2013), nasal prefix syncope is not an innovation which can be attributed to the most common recent ancestor. The fact that it is only observed for the first time in South Kikongo in 1652 also means that it could not date back to a hypothetical more recent common ancestor of those subgroups where it is most fully represented, i.e. South, East and Central. Their fragmentation must considerably predate 1652 . Hence, prefix reduction cannot be taken as a shared innovation indicative of genealogical relationships within the KLC.

We argue that its current-day spread can be most plausibly accounted for by a classical process of dialectal diffusion (Andersen 1988), whereby the change started in a center of innovation or focal area and gradually spread to peripheral relic areas. The fact that only one member of the North cluster and only the southernmost members of the West cluster are affected pleads in favor of this scenario. The presence of the innovation in Kiyaka but not in its nearest eastern relative, Kisuku, both not core members of the KLC, points in the same direction, i.e. 
that nasal prefix syncope spread to Kiyaka through contact with its East Kikongo neighbors. The contact-induced dialectal diffusion hypothesis becomes even more plausible if we take into account the present-day distribution of all prefix reduction types (cf. Map 3) as well as the available diachronic Kikongo-internal data, as we have done in $\$ \$ 4$ and 5 .

The linguistic evidence presented in those sections suffices to posit that the reductions of the noun prefixes of classes 1, 3, 4, 7, 8 and 15 were innovations that spread successively through the KLC and that their most plausible center of origin was the center of the southern zone. On the basis of the historical data, two possible centers of diffusion actually remain, i.e. the central South Kikongo area in present-day northern Angola and the southern part of the West Kikongo area in today's Cabinda. The latter cannot be excluded, because we find evidence for $m u-$, $m i-, k i$ - and $k u$-reduction in the earliest West Kikongo documentation from the end of the 18th century while we do not have earlier evidence available for this part of the KLC. However, reduction for classes 1 and 3 had already reached step 3 by the end of the 17th century for the central South Kikongo area, while for those same classes in southern West Kikongo, only step 2 was observed a century later. If we therefore consider the actual spread of these successive innovations, their current-day distribution would be difficult to account for with Kakongo as the actual center of innovation. The different isoglosses rather radiate as concentric circles from the center of the southern part of the KLC. The least diffused reduction types occur in the zones immediately bordering the South Kikongo cluster, i.e. the westernmost East Kikongo varieties, the southernmost West Kikongo varieties, the Central Kikongo varieties and Cilaadi, the southernmost North Kikongo variety. If we took Kakongo as the center of innovation it would be difficult to explain why, for instance, East Kikongo varieties, such as Kintandu and Kimbata, irregularly manifest $k i$ - reduction, but not the immediately neighboring and most closely related West Kikongo varieties.

\section{The social ecology of prefix reduction}

If prefix reduction as a process is an innovation that indeed started in the course of the 17th century in the southern part of the KLC, it is striking that its different manifestations spread relatively rapidly, though with decreasing strength, to neighboring areas where closely related varieties were spoken. Trudgill (2011:1-14) establishes an interesting correlation between the rate of linguistic change and two major social factors, i.e. the relative degree of contact vs. isolation and the relative social stability vs. instability of speech communities. He argues that conservative language varieties tend to be those which are relatively more geographically 
isolated and relatively more stable socially than the more innovating language varieties. Considered from such a sociolinguistic point of view, the southern part of the KLC would not be an unlikely center of innovation, since it is situated in the heartland of the Kongo kingdom. The 17th-century Kikongo data in which prefix reduction is first documented originate from the area around Mbanza Kongo, the former capital of the Kongo kingdom.

In the 17th-century Kongo, kings were at the zenith of their power. This was the outcome of a gradual process of political centralization whereby originally federated and rather independent provinces were increasingly forced into submission to central administration (Thornton 2001). In the late 16th and early 17th centuries, a number of developments, such as Portuguese military support, control of trade routes supplying the Portuguese colony at Luanda from the interior and the investment of trade wealth in slave soldiers and laborers, played into the hands of the powers that be and reinforced the direct rule of Kongo kings over their dominion (Hilton 1985: 103). This caused considerable social upheaval in the subjugated areas. The elite's slave-based political and economic power entailed, for instance, a shift in kinship ideology. The traditionally normative kinship pattern of exogamous, matrilineal descent groups controlling access to land, which was closely linked with an agriculture-based economy, evolved into a system of patrilineal descent categories which had to assure the concentration of trade-based wealth and power in the hands of the male descendants of the king and his nobility (Hilton 1983). This created a fundamental division with the commoners who lived in so-called mavata or rural villages, perpetuated a kin-based agricultural economy and still controlled land outside the seats of economic and political power, commonly known as mbanza (Thornton 1983: 16; Hilton 1985:90). A spatial division thus strengthened the existing social, political and economic hierarchy.

Moreover, as 17th-century European chroniclers testify to, this social and economic opposition was increasingly conceived as an ethnic divide between ruling outsiders who came from the interior and natives whom they had subdued (Thornton 1983:15). The nobility was known as Mexicongos or Ashikongo, a name still surviving today in the glossonym Kisikongo referring to the South Kikongo variety spoken in the vicinity of the kingdom's former capital of Mbanza Kongo. Thornton (1983:15) highlights the fact that the people of the capital "ruled not only in areas where their dialect prevailed, but in the highest positions of the kingdom." From lists of different peoples and languages within the Kongo, as those provided by De Cadornega in 1680 (Pauta das Naçoens do Gentio do Reino de Congo de differente lingoa e costumes; see Delgado 1940:193-194), we know that the kingdom was not a monocultural or monolingual bloc and that different ethno-linguistic identities co-existed. From the viewpoint of the KLC, the principal southern provinces were situated in areas where varieties of South Kikongo 
are currently spoken, and the most important northern and eastern provinces in Central and East Kikongo speech zones. The kingdom's northern border coincided more or less with the Congo River, north of which the West and North Kikongo clusters are situated.

Given the historical context sketched above, it is plausible to assume that strong centripetal forces were at work during the 16th and 17th centuries on different levels, not only politically, socially and economically, but also linguistically. Economically, Kongo kings drew their power from commerce revenues and attempted to ensure that all trade passed through their capital (Thornton 1983; Hilton 1985). Being connected to different long-distance trade routes linking the Atlantic coast with the interior (Vansina 1962), Mbanza Kongo was a central node of communication and contact and thus no doubt an important vector of language change. Innovations initiated there were more easily spread to other regions than those initiated elsewhere in the KLC. Being at the heart of a strongly branched trade network, Mbanza Kongo not only attracted merchants from abroad, but also from more peripheral areas of the KLC. Their knowledge of South Kikongo was certainly helpful to boost trade profits. This association with commercial success may have helped spread the language's fame within the kingdom, where other Kikongo varieties were spoken, but also far beyond, for instance to important trade ports in the coastal area of Kakongo and Loango, where West Kikongo varieties were spoken.

Moreover, it is hard to imagine that the elite's language was on an equal footing with that of their rural subjects. If anything, the nobility even instrumentalized language, and more specifically the written language, as a device to strengthen their grip on the provinces. Literacy came in the slipstream of Christianity, which the aristocracy also monopolized as a legitimating ideology independent of indigenous territorial cults (Thornton 1983:64; Hilton 1985:103). As demonstrated by Hilton (1985:79-85), literacy - in both Portuguese and Kikongo - helped the central powers in several ways to improve its administration and to bring center and periphery closer together. It facilitated communication with the provinces, especially when travel became faster during the 16th century thanks to a number of technological innovations combined with slave labor. Provincial governors employed literate people from the central capital as secretaries and council members. Literacy also cleared the way for European-style formal education. In close collaboration with foreign missionaries, Kongo kings founded schools in Mbanza Kongo and the provincial capitals. Provincial dukes sent their sons and nephews to the capital for schooling and teachers were sent out from the capital to the rural areas. All this not only contributed to the spread of literacy and the values and standards of the nobility, but also to the penetration of the elite's specific variety of Kikongo into the provinces where other varieties prevailed. In the course of the 
16th and 17th centuries, command of this high-prestige South Kikongo variety no doubt became an increasingly important means of social promotion within the kingdom.

Given the fundamental social, spatial and ethnolinguistic divisions that existed between the elite and the common people, it is unlikely that the use of central South Kikongo became generalized throughout the kingdom. Nevertheless, thanks to the high prestige with which it was invested as language of the ruling classes, who also monopolized access to political office, capital and slave labor in the provinces, central South Kikongo certainly had its impact on other Kikongo varieties. Children of noblemen by local or slave women may have been important actors in this process of language convergence. In spite of their mothers' low birth, these children joined the patrilineal descent group of their titled father with its privileges, such as schooling. This arguably gave rise to situations of individual bilingualism, or rather diglossia. At home they spoke their mother's local tongue, at school or in other less intimate settings they used South Kikongo, the aristocracy's language, and they probably also mastered a number of registers in between. Generation upon generation these Kongo children may have constituted important cohorts of diglossic speakers acting as intermediaries between the local and the central levels. They had a foot in both worlds and loyalty to both cultures. Their numbers may have been considerable, since their noble fathers were more likely than other men to have multiple wives in the polygamous society that Kongo used to be. They were thus perfectly suited, both statistically and in terms of social profile, to be transmitters of language change from the center to the periphery. Admittedly, this is a highly speculative scenario that needs to be corroborated by historical research. However, it is well known from variation studies how the manipulation of linguistic variation and different linguistic varieties is instrumental for the construction of social identity and may underlie the spread of linguistic innovation (Kiesling 2013).

Under the circumstances sketched here, prefix reduction may well have become seen as a sociolinguistic marker of high-class speech characteristic of the kingdom's elite. Given the high prestige with which it was invested and the role it played in interregional communication, South Kikongo may have easily emitted successive waves of prefix reduction to other dialect areas even far beyond Kongo's borders. This converging linguistic impact may have continued long after the battle of Mbwila in 1665 unleashed centrifugal forces within the kingdom with Mbanza Kongo and Mbanza Soyo as the main antagonists. It was the beginning of a period of devastating civil wars, which led to the disintegration of the central state and to the decline of Mbanza Kongo as the power center. Despite the loss of its political and economic importance, the kingdom's former capital continued to be a highly significant cultural landmark and an important symbol of shared identity. 


\section{Conclusions}

We have presented empirical diachronic evidence for a classical process of contact-induced dialectal diffusion in a language with a predominantly oral tradition. This is quite unique within the field of African historical linguistics and possible thanks to a unique diachronic Kikongo corpus with a time depth of over four centuries, which we are progressively making exploitable for semi-automated linguistic research. Through a case study of prefix reduction, this diachronic corpus enabled us to address two fundamental questions that can rarely be addressed with regard to the evolution of African languages, i.e. the problems of actuation and transmission (Weinreich et al. 1968). We usually lack the empirical evidence to determine when a given change starts out from the minimal synchronic variation that always exists within and between idiolects and how it subsequently spreads through a speech community, and sometimes even into neighboring communities. Although the diachronic linguistic data presented here remain fragmentary and do not allow us to document the entire three-stage evolution of prefix reduction for each of the historical Kikongo varieties, we have succeeded in advancing sufficient data to show where, when and how the process of prefix reduction began and how it spread through different speech communities within the KLC.

We have argued that this innovation started out from synchronic variation within 17th-century central South Kikongo as commonly spoken in the heartland of the Kongo kingdom and that it subsequently spread to other parts of the KLC, both within the confines of the area under direct royal control and beyond. From the data considered here, we can conclude that this loss of sounds within the noun prefix, in some cases leading to total prefix loss, first affected nasal-initial prefixes and was subsequently extended to other prefixes. The variable extent to which these different types of prefix reduction penetrated the KLC suggests that they started out and began to spread successively and gradually, with an uneven impact on neighboring speech communities. It is striking that varieties belonging to different clusters, all spoken to the north of the kingdom's capital, are more profoundly affected by this innovation than varieties spoken to its south, such as present-day Kitsotso and Dihungu and the late 18th-century Kikongo spoken at Bengo near Luanda. This means that the zones mainly situated in current-day Cabinda and the Lower Congo Province of the DRC were much more closely connected to the kingdom's heartland, with which they formed a linguistic convergence area.

We not only reconstructed where, when and how these linguistic innovations started, but we also attempted to trace why they were copied by others. Thanks to the unequalled insights we have into the previous five hundred years 
of Lower Congo history, we have been able to discuss a number of social, cultural and historical factors that may have conditioned prefix reduction. Although the proposed scenarios are still very tentative, evidence brought forward by historians allows us to assume that prefix reduction started out in the South Kikongo variety spoken by the kingdom's elite who concentrated in and around the capital at Mbanza Kongo, but also occupied prestigious positions throughout the state. Thanks to strong political centralization and advanced economic integration through trade, this specific variety of Kikongo played a central role in interregional communication within and beyond the Kongo kingdom. In the kingdom's heyday, it must have been a key to social promotion and commercial success, especially in those areas of the kingdom where clearly distinct varieties of Kikongo were spoken. The positive social meaning with which a highly distinctive phonological innovation like prefix reduction may have easily become charged under such circumstances (Hay \& Drager 2007) facilitated its trickling down into local varieties of Kikongo after it had first diffused little by little through the South Kikongo lexicon. The social status which central South Kikongo built up as a language of the elite and literate during the heyday of the kingdom, i.e. during the 16th and early 17th centuries, undoubtedly did not stop radiating as soon as the central state started to disintegrate as a consequence of a series of devastating civil wars from the late 17th century onwards. Successive waves of prefix reduction continued to be emitted from the center to the periphery, though with an increasingly lower impact. Maps 1, 2 and 3 (included as addenda) summarize the data for three different time periods.

In sum, then, thanks to a unique Kikongo corpus that starts in the 17th century, we have been able to provide diachronic empirical evidence for different phases of a historical process of dialect diffusion in an oral language, which is unprecedented in Bantu historical linguistics, and rather exceptional in African linguistics. We have also reconstructed the 'social ecology' of this language change and hence opened up a new pathway for discovery. As a next goal, the historical sociolinguistic theory elaborated here may be contrasted with other parameters of linguistic variation in order to verify whether they manifest a similar spreading.

\author{
Abbreviations \\ $\mathrm{AUG}_{\mathrm{x}} \quad$ augment of class $\mathrm{x}$ \\ cl. class \\ CON connective \\ DEM demonstrative \\ FV final vowel
}




$\begin{array}{ll}\mathrm{N} & \text { homorganic nasal } \\ \mathrm{NP}_{\mathrm{X}} & \text { noun prefix of class } \mathrm{x} \\ \mathrm{PC}_{\mathrm{x}} & \text { pronominal concord of class } \mathrm{x} \\ \mathrm{PL} & \text { plural } \\ \mathrm{PROX} & \text { proximal } \\ \text { SEP } & \text { separative } \\ \text { SG } & \text { singular } \\ \mathrm{X} & \text { class or person (with SG = singular, and } \mathrm{PL}=\text { plural) }\end{array}$

\section{References}

Ambouroue, Odette. 2007. Eléments de description de l'orungu, langue bantu du Gabon (B11b). Brussels: Université libre de Bruxelles Ph.D. dissertation.

Andersen, Henning. 1988. Center and periphery: Adoption, diffusion, and spread. In Jacek Fisiak (ed.), Historical dialectology: Regional and social, 39-83. Berlin: Mouton de Gruyter. DOI: $10.1515 / 9783110848137.39$

Anonymous. 1890?. Dictionnaire français-fiote, dialecte du Kakongo, par les missionnaires de la Congrégation du Saint-Esprit et du Saint-Coeur de Marie, Mission de Landana, Préfecture apostolique du Bas-Congo. Paris: Librairie orientale et américaine, Maisonneuve frères.

Atkins, Guy. 1954. An outline of Hungu grammar. Garcia de orta: Revista da Junta de Missões Geográficas e de Investigações do Ultramar 2. 145-164.

Baka, Jean. 1992. Essai de description du tso:tso, parler ko:ngo du nord de l'Angola. Brussels: Université libre de Bruxelles mémoire de DEA.

Balandier, Georges. 1965. La vie quotidienne au royaume de Kongo du XVIe au XVIIIe siècle. Paris: Hachette. DOI: 10.1017/s0021853700008926

Bell, Alan. 1972. The development of syllabic nasals in the Bantu noun class prefixes mu-, miand ma-. Anthropological Linguistics 14(2). 29-45.

Bentley, William Holman. 1887. Dictionary and grammar of the Kongo language as spoken at San Salvador, the ancient capital of the Old Kongo empire, West Africa. London: Baptist Missionary Society and Trübner \& Co.

Bentley, William Holman. 1895. Appendix to the dictionary and grammar of the Kongo language as spoken at San Salvador, the ancient capital of the Old Kongo empire, West Africa. London: Baptist Missionary Society and Kegan Paul, Trench, Trübner \& Co.

Bittremieux, Léo. 1943-44. De spraakkundige prefixen en het wegvallen van sommige prefixen in het Kikongo. Æquatoria 6/7. 104-111, 101-113, 181-188.

Bonneau, Joseph. 1956. Grammaire pounoue et lexique pounou-français. Montpellier: Imprimerie Charité.

Bontinck, François (ed.). 1970. Diaire congolais (1690-1701) de Fra Luca da Caltanisetta, traduit du manuscrit italien inédit et annoté par François Bontinck, C.I.C.M. Louvain/Paris: Editions Nauwelaerts/Béatrice-Nauwelaerts. DOI: 10.1017/s0041977x00129088

Bontinck, François \& Damase Ndembe Nsasi. 1978. Le catéchisme kikongo de 1624. Ré-édition critique. Brussels: Académie royale des sciences d'outre-mer.

DOI: $10.1017 / \mathrm{s} 0021853700018259$

Bostoen, Koen, Odjas Ndonda Tshiyayi \& Gilles-Maurice de Schryver. 2013. On the origin of the royal Kongo title ngangula. Africana Linguistica 19. 53-83. 
Bouka, Léonce Yembi. 1989. Eléments de description du kaamba, parler bantou de la République Populaire du Congo (Groupe Koongo, H17b). Brussels: Université libre de Bruxelles mémoire de licence spéciale.

Brinkman, Inge. 2014. Interpreters in the Kongo kingdom, 16th-19th century. Paper presented at Robert Ross's Valedictory Workshop, Leiden University, Department of African Languages and Cultures. September 17-18.

Brusciotto à Vetralla, Hyacintho. 1659. Reguloe quoedam pro difficillimi Congensium idiomatis faciliori captu ad grammaticae normam redactoe. Rome: Sacra Congregatio de Propaganda Fide.

Butaye, René. 1909. Dictionnaire kikongo-français, français-kikongo. Roulers, Belgium: Jules De Meester.

Butaye, René. 1910. Grammaire congolaise. Roulers, Belgium: Jules De Meester.

Carrie, Monseigneur. 1888. Grammaire de la langue fiote, dialecte du Kakongo. Loango: Imprimerie de la Mission.

Carter, Hazel. 1970. Consonant reinforcement and Kongo morphology. African Language Studies 11. 113-146.

Carter, Hazel \& João Makondekwa. 1987. Kongo language course: Maloongi makikoongo, a course in the dialect of Zoombo, Northern Angola. Madison, WI: African Studies Program, University of Wisconsin.

Chambers, Jack K. \& Peter Trudgill. 1998. Dialectology. Cambridge: Cambridge University Press. DOI: $10.1017 /$ cbo9780511805103

Coene, Alfons. 1960. Kikongo : Notions grammaticales. Vocabulaire français-kikongo, néerlandais, latin. Tumba: Imprimerie Maison Catholique.

Crowley, Terry \& Claire Bowern. 2010. An introduction to historical linguistics. Oxford: Oxford University Press.

Curtin, Philip D. \& Jan Vansina. 1964. Sources of the nineteenth century Atlantic slave trade. Journal of African History 5(2). 185-208. DOI: 10.1017/s0021853700004801

Cuvelier, Jean. 1946. Lancien royaume de Congo. Bruges: Desclée De Brouwer.

Cuvelier, Jean. 1953. Documents sur une mission française au Kakongo 1766-1776 avec introduction et annotations. Brussels: Institut royal colonial belge.

Cysouw, Michael \& Jeff Good. 2013. Languoid, doculect, glossonym: Formalizing the notion "language". Language Documentation \& Conservation 7. 331-359.

Daeleman, Jan. 1966. Morfologie van naamwoord en werkwoord in het Kongo (Ntandu) met ontleding van het foneemsysteem. Leuven: Katholieke Universiteit Leuven Ph.D. dissertation.

Daeleman, Jan. 1983. Les réflexes du proto-bantu en ntandu (dialecte koongo). In Clémentine Faïk-Nzuji Madiya \& Erika Sulzmann (eds.), Mélanges de culture et de linguistique africaines publiés à la mémoire de Leo Stappers, 331-397. Berlin: Dietrich Reimer.

De Blois, Kees F. 1970. The augment in the Bantu languages. Africana Linguistica 4. 85-165.

de Cannecattim, Bernardo Maria. 1805. Collecção de observações grammaticaes sobre a lingua Bunda ou Angolense compostas. Lisbon: Impressão Regia.

De Clercq, Louis. 1921. Grammaire du kiyombe. Brussels: Goemare.

De Grauwe, Jan. 2009. Lexique yoómbe-français, avec index français-yoómbe (bantu H16c). Tervuren, Belgium: Musée royal de l’Afrique centrale.

De Kind, Jasper. 2012. Taalvariatie in het Kikongo van Angola vanuit historisch perspectief: fonologie en morfologie. Ghent: Universiteit Gent MA thesis.

De Kind, Jasper, Gilles-Maurice de Schryver \& Koen Bostoen. 2012. Pushing back the origin of Bantu lexicography: The Vocabularium Congense of 1652, 1928, 2012. Lexikos 22. 159-194. DOI: $10.5788 / 22-1-1002$ 
Delgado, José Matias (ed.). 1940. António de Oliveira de Cadornega: História geral das guerras angolanas 1680 (Anotado e corrigido por José Matias Delgado, tomo III). Lisbon: Agência Geral do Ultramar.

de Marees, Pieter. 1602. Beschryvinghe ende historische verhael van het gout koninkrijck van Gunea anders de gout-custe de Mina genaemt, liggende in het deel van Africa. Amsterdam: Cornelisz Calesz.

Derouet, Jean. 1896. Dictionnaire français-fiote, dialecte vili. Loango: Imprimerie de la Mission Catholique.

de Schryver, Gilles-Maurice \& Rachélle Gauton. 2002. The Zulu locative prefix ku- revisited: A corpus-based approach. Southern African Linguistics and Applied Language Studies 20(4). 201-220. DOI: 10.2989/16073610209486311

de Schryver, Gilles-Maurice, Rebecca Grollemund \& Koen Bostoen. 2013. A diachronic phylogenetic approach to the internal classification of the Kikongo group. Paper presented at the 43rd Colloquium on African Languages and Linguistics, Leiden University, the Netherlands. August 26-28.

Doke, Clement Martyn. 1935. Early Bantu literature: The age of Brusciotto. Bantu Studies 9(1). 87-114. DOI: 10.1080/02561751.1935.9676360

Dom, Sebastian. 2013. Tijd en aspect in Kikongo (Bantoe H16): Een comparatieve benadering van het Kimbata, Kimbeko, Kinkanu, Cizali, Ciwoyo en Kisolongo. Ghent: Universiteit Gent MA thesis.

Drieghe, Sharah. 2014. Het oudste Kakongo woordenboek (1772): Digitalisatie, lexicografische analyse en historisch-taalkundige studie. Ghent: Universiteit Gent MA thesis.

Futi, João Maria. 2012. Essai de morphologie lexicale du Cisuundi du Cabinda (Angola). Paris: L'Harmattan.

Greenberg, Joseph H. 1966. Language universals. The Hague: Mouton. DOI: 10.2307/411706

Guinness, Henry Grattan. 1882. Grammar of the Congo language as spoken two hundred years ago, translated from the Latin of Brusciotto. London: Hodder \& Stoughton.

Guthrie, Malcolm. 1948. The classification of the Bantu languages. London: Published for the International African Institute by the Oxford University Press. DOI: 10.2307/1156267

Guthrie, Malcolm. 1964. Bantu languages in 'Polyglotta Africana'. Sierra Leone Language Review 3. 59-64.

Hair, Paul E. H. 1963. Koelle at Freetown: An historical introduction. Sigismund Wilhelm Koelle's Polyglotta Africana. Unveränderter Nachdruck der Ausgabe London 1854. Vermehrt durch eine historische Einführung von P.E.H. Hair und einen Wortindex von David Dalby. Graz: Akademische Druck - u. Verlagsanstalt.

Hay, Jennifer \& Katie Drager. 2007. Sociophonetics. Annual Review of Anthropology 36. 89-103. DOI: 10.1146/annurev.anthro.34.081804.120633

Hilton, Anne. 1983. Family and kinship among the Kongo south of the Zaire river from the sixteenth to the nineteenth centuries. The Journal of African History 24(2). 189-206. DOI: $10.1017 / \mathrm{s} 0021853700021939$

Hilton, Anne. 1985. The Kingdom of Kongo. Oxford: Clarendon Press/Oxford University Press. DOI: $10.1163 / 157006692 \times 00112$

Hyman, Larry Michael \& Armindo Saul Atelela Ngunga. 1997. Two kinds of moraic nasals in Ciyao. Studies in African Linguistics 26(2). 131-163.

Jacquot, André. 1982a. Étude descriptive de la langue laadi. Lille, France: Atelier National de Reproduction des Thèses. 
Jacquot, André. 1982b. Lexique laadi (koongo). Paris: Société d'études linguistiques et anthropologiques de France, Office de la recherche scientifique et technique outre-mer.

Jadin, Louis. 1968. Relations sur le Congo et l'Angola tirées des archives de la Compagnie de Jésus 1621-1631. Brussels: Academia Belgica.

Kamba Muzenga, Jean-Georges. 1988. Comportement du préfixe nominal de classe 5 en bantou. Annales Æquatoria 9. 89-131.

Katamba, Francis. 2003. Bantu nominal morphology. In Derek Nurse \& Gérard Philippson (eds.), The Bantu languages, 103-120. London: Routledge.

Kawalya, Deo, Koen Bostoen \& Gilles-Maurice de Schryver. 2014. Diachronic semantics of the modal verb -sóból- in Luganda: A corpus-driven approach. International Journal of Corpus Linguistics 19(1). 60-93. DOI: 10.1075/ijcl.19.1.03kaw

Kiesling, Scott F. 2013. Constructing identity. In J. K. Chambers \& Natalie Schilling-Estes (eds.), The handbook of language variation and change, 2nd edn. Oxford: Wiley-Blackwell.

Kisilu Meso, Jean Samuel. 2001. Morphologie flexionnelle du kimboma. Kinshasa: Institut Pédagogique National mémoire de licence.

Knappert, Jan. 1971. Swahili Islamic poetry. Leiden: Brill. DOI: 10.2307/1594723

Koelle, Sigismund Wilhelm. 1854. Polyglotta Africana, or a comparative vocabulary of nearly three hundred words and phrases in more than one hundred distinct African languages. London: Church Missionary House.

Lafon, Michel. 1994. Shona class 5 revisited: A case against ${ }^{*}$ ri- as class 5 nominal prefix. Zambezia: The Journal of Humanities of the University of Zimbabwe 21(1). 51-80.

Laman, Karl Edward. 1912. Grammar of the Kongo language (Kikongo). New York: Christian Alliance Publishers.

Lembe-Masiala, Nathalis. 2007. Le káandu chez les Basolongo du Bas-Congo (RDC). Ghent: Université de Gand. Ph.D. dissertation.

Mabiala, Jean-Noël. 1992. Etudes du kiyoombi, langue kongo du Congo. Lyon: Université Lumière Lyon 2 mémoire de DEA.

Mabiala, Jean-Noël. 1999. Phonologie comparative et historique du koongo. Lyon: Université Lumière Lyon $2 \mathrm{Ph} . \mathrm{D}$. dissertation.

Maho, Jouni Filip. 2009. NUGL online: The online version of the New Updated Guthrie List, a referential classification of the Bantu languages. (Online file: http://goto.glocalnet.net/ mahopapers/nuglonline.pdf; last accessed 16 March 2015.).

Makokila, André. 2012. Le système verbal du kimanyaanga : approche structuraliste. Lubumbashi, Democratic Republic of the Congo: Université de Lubumbashi mémoire de DES.

Mavoungou, Paul Achille \& Bernard Plumel. 2010. Dictionnaire yilumbu-français. Libreville, Gabon: Éditions Raponda Walker.

Meeussen, Achille Emiel. 1967. Bantu grammatical reconstructions. Africana Linguistica 3. 79-121.

Merolla da Sorrento, Girolamo. 1692. Breve, e succinta relatione del viaggio nel regno di Congo nell'Africa meridionale. Naples: Francesco Mollo.

Mfoutou, Jean-Alexis. 1985. Esquisse phonologique du kidoondo : un dialecte koongo de la République Populaire du Congo. Brazzaville: Université Marien Ngouabi mémoire de DES.

Mingas, Amélia Arleta. 1994. Étude grammaticale de l'iwoyo (Angola). Paris: Université René Descartes Paris 5 Ph.D. dissertation.

Mpanzu, Luzayamo. 1994. Eléments de description du zombo, parler kongo H16k d'Angola. Brussels: Université libre de Bruxelles mémoire de licence spéciale. 
Mufwene, Salikoko S. 2001. The ecology of language evolution. Cambridge: Cambridge University Press. DOI: 10.1017/s0047404503234059

Mufwene, Salikoko S. 2013. Kikongo-Kituba. In Susanne Maria Michaelis, Philippe Maurer, Martin Haspelmath \& Magnus Huber (eds.), The survey of pidgin and creole languages. Volume 3: Contact languages based on languages from Africa, Asia, Australia, and the Americas, 3-13. Oxford: Oxford University Press.

Ndinga-Koumba-Binza, Hugues Steve. 2000. Phonologie du civili de mayumba : langue bantu du Gabon (H12a). Libreville, Gabon: Université Omar Bongo MA thesis.

Ndonga Mfuwa, Manuel. 1995. Systématique grammaticale du kisikongo (Angola). Paris: Université René Descartes Paris 5 Ph.D. dissertation.

Ngunga, Armindo Saul Atelela. 1997. Class 5 allomorphy in Ciyao. Studies in African Linguistics 26(2). 165-192.

N'landu Kitambika. 1994. Eléments de description du kisuundi (H13b), parler de la République du Congo. Brussels: Université libre de Bruxelles mémoire de licence spéciale.

Nsayi, Bernard. 1984. Approche du kibeembe : première et deuxième articulation. Paris: Université René Descartes Paris 5 Ph.D. dissertation.

Nurse, Derek \& Thomas J. Hinnebusch. 1993. Swahili and Sabaki: A linguistic history (with a special addendum by Gérard Philippson). Berkeley, CA: University of California Press.

Philippson, Gérard \& Pierre Boungou. 1999. Éléments de tonologie beembe (H.11). In Jean Alain Blanchon \& Denis Creissels (eds.), Issues in Bantu tonology, 83-107. Cologne: Rüdiger Köppe.

Piper, Klaus. 1977. Elemente des Suku. Zur Phonologie und Morphologie einer Bantusprache. Leiden: Rijksuniversiteit Leiden Ph.D. dissertation.

Proyart, Liévin-Bonaventure. 1776. Histoire de Loango, Kakongo, et autres royaumes d'Afrique; rédigée d'après les mémoires des préfets apostoliques de la mission françoise; enrichie d’une carte utile aux navigateurs. Paris/Lyon: C.P. Berton \& N. Crapart/Bruyset-Ponthus.

Randles, William G. L. 1968. L’ancien royaume du Congo des origines à la fin du XIXe siècle. Paris: Mouton. DOI: $10.2307 / 1158890$

Raponda Walker, André. 1934. Dictionnaire mpongwe-français. Metz, France: La Libre Lorraine.

Saccardo, Graziano. 1983. Congo e Angola con la storia dell'antica missione dei Cappuccini, vol. 3. Venice: Curia Provinciale dei Cappuccini. DOI: 10.1017/s0021853700023355

Samarin, William John. 2013. Versions of Kituba's origin: Historiography and theory. Journal of African Languages and Linguistics 34(1). 111-181. DOI: 10.1515/jall-2013-0004

Tavares, José Lourenço. 1915. Gramática da língua do Congo (kikongo) (dialecto kisolongo). Luanda, Angola: Imprensa nacional da colónia de Angola.

Thornton, John K. 1983. The Kingdom of Kongo: Civil war and transition, 1641-1718. Madison, WI: University of Wisconsin Press. DOI: 10.1017/s0021853700037208

Thornton, John K. 2001. The origins and early history of the Kingdom of Kongo, c. 1350-1550. International Journal of African Historical Studies 34(1). 89-120. DOI: 10.2307/3097288

Trudgill, Peter. 2011. Sociolinguistic typology: Social determinants of linguistic complexity. Oxford: Oxford University Press. DOI: 10.1075/sl.36.4.11sta

Tuckey, James Hingston. 1818. Narrative of an expedition to explore the river Zaire, usually called the Congo, in South Africa, in 1816: Under the direction of J. K. Tuckey to which is added the journal of Professor Smith; some general observations on the country and its inhabitants and an appendix containing the natural history of that part of the kingdom of Congo through which the Zaire flows. London: John Murray. DOI: 10.5962/bhl.title.28651 
van Bulck, Vaast. 1954. Het oudste Kakongo-woordenboek (1768-1775) - E. H. Jean-Joseph Descourvières (1743-1804). Kongo-Overzee 20(2). 97-125.

Van den Eynde, Karel. 1968. Eléments de grammaire yaka : phonologie et morphologie flexionnelle. Kinshasa: Université Lovanium. DOI: 10.1017/s0041977x00145707

van Gheel, Joris. 1652. Vocabularium Latinum, Hispanicum, e Congense. Ad Usum Missionariorû transmittendorû ad Regni Congo Missiones. Rome: National Central Library, Fundo Minori 1896, MS Varia 274.

Vansina, Jan. 1962. Long-distance trade-routes in Central Africa. Journal of African History 3(3). 375-390. DOI: 10.1017/s0021853700003303

van Wing, Joseph. 1921. Etudes Bakongo, histoire et sociologie. Brussels: Goemare.

van Wing, Joseph \& Constant Penders. 1928. Le plus ancien dictionnaire bantu. Het oudste Bantu-Woordenboek. Vocabularium P. Georgii Gelensis. Louvain, Belgium: J. Kuyl-Otto.

DOI: $10.2307 / 1155132$

Vega, Carlos B. 2010. Spanish-English grammar. Hauppauge, NY: Barron's.

Weber, Eugen. 1924. Die portugiesische Reichsmission im Königreich Kongo: 1491-1548 (Abhandlungen aus Missionskunde und Missionsgeschichte 42). Aachen, Germany: Xaveriusverlag.

Weinreich, Uriel, William Labov \& Marvin Herzog. 1968. Empirical foundations for a theory of language change. In Wilhelm P. Lehmann \& Yakov Malkiel (eds.), Directions for historical linguistics: A symposium, 95-188. Austin, TX: University of Texas Press.

Westlind, Nils. 1887. Nkanda ubadukulwanga longuka tanga/Läsebok för dem som skola börja att läsa på kongospråket. Stockholm: Helmlandvännens tryckeri.

Westlind, Nils. 1888. Grammatikaliska Anmärkningar öfver Kongospråket. Mukimbungu, Democratic Republic of the Congo: Missionsstation (Swedish Missionary Society).

\section{Appendix}

http://www.dx.doi.org/10.1075/dia.32.2.01bos.additional

\section{Résumé}

Dans cet article, nous reconstruisons le déclenchement et la diffusion d'une innovation phonologique au sein du groupe kongo situé à proximité de l'embouchure du Congo en Afrique centrale, à savoir la réduction préfixale. Nous soutenons que ce changement linguistique s'est répandu à partir d'une région focale qui coïncide avec le centre même du royaume Kongo, et ce suivant un processus classique de diffusion dialectale. Nous fondant sur un corpus unique du kikongo qui commence au XVII ${ }^{\mathrm{e}}$ siècle, nous avons pu faire ce qui est d'habitude difficile, voire impossible en linguistique historique bantoue : réunir des preuves empiriques étayant différentes phases de ce processus diachronique. En outre, et de manière aussi exceptionnelle en linguistique africaine, nous avons une idée assez claire de "l'écologie sociale » de ce changement linguistique. Nous soutenons que la cen- 
tralisation politique et l'intégration économique dans le royaume Kongo ont facilité le transfert de ce changement dû au contact ainsi que sa diffusion à travers des parlers étroitement apparentées.

\section{Zusammenfassung}

In diesem Artikel rekonstruieren wir die Aktuation und Vermittlung der Prefix-Reduktion. Diese phonologische Innovation liegt innerhalb des Kikongo Sprachen-Clusters, das im Gesamtraum des Unterkongo in Zentralafrika angesiedelt ist. Wir argumentieren, dass sich diese Veränderung als klassischer Prozess dialektaler Diffusion von einem zentralen, mit dem Landesinneren des Königreiches Kongo übereinstimmenden Gebiet ausbreitete. Durch einen einzigartigen Kikongo Korpus der im 17. Jahrhundert beginnt, können wir - was in der historischen Linguistik der Bantusprachen bislang schwierig, wenn nicht unmöglich war - diachron-empirische Nachweise für verschiedene Phasen dieses Prozesses vorlegen. Überdies ist es für Afrikanische Linguistik außergewöhnlich, dass wir einen recht guten Einblick in die 'soziale Ökologie' der Sprachveränderung haben. Wir argumentieren, dass die politische Zentralisierung und die ökonomische Integration innerhalb des Königreiches Kongo die kontaktbedingte Diffusion zwischen eng verwandten Sprachvariationen unterstützten.

\section{Corresponding author's address}

Koen Bostoen

Ghent University

Department of Languages and Cultures: Africa

Rozier 44

9000 GHENT

Belgium

koen.bostoen@UGent.be 


\section{Maps}

All maps depict present-day boundaries and localities.

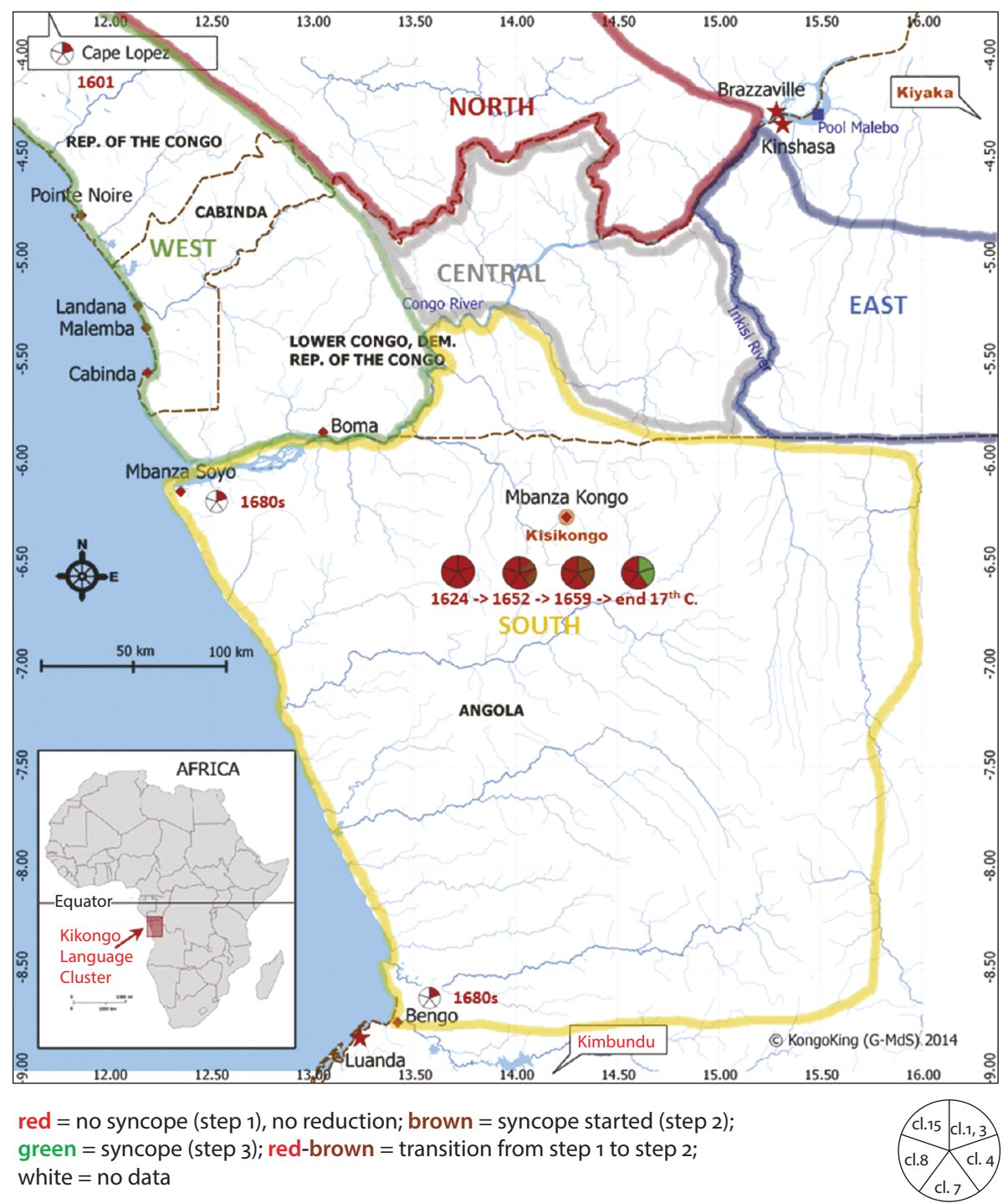

Map 1. Prefix reduction in the KLC, 1600s - 1690s 


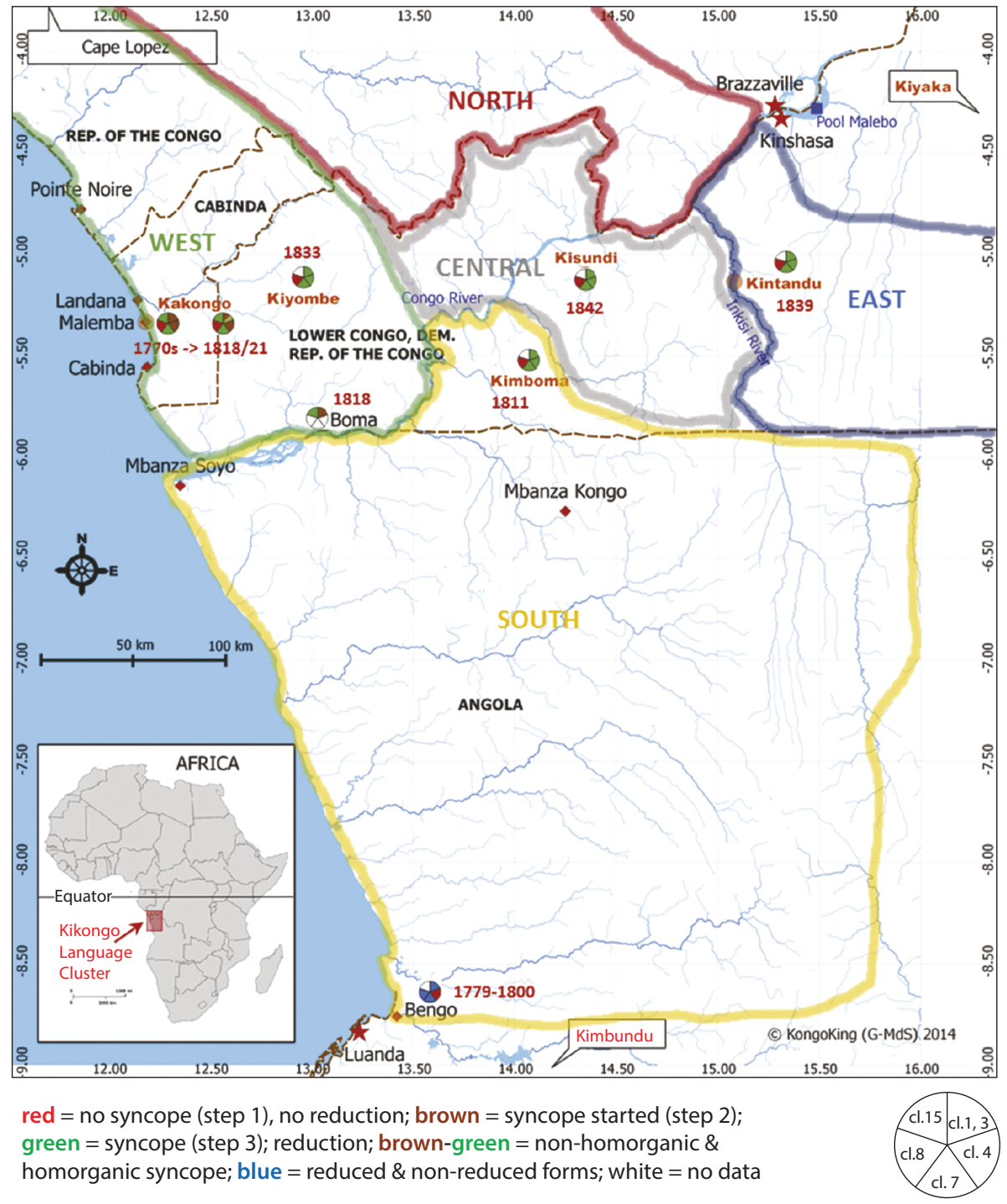

Map 2. Prefix reduction in the KLC, 1770s - 1840s 


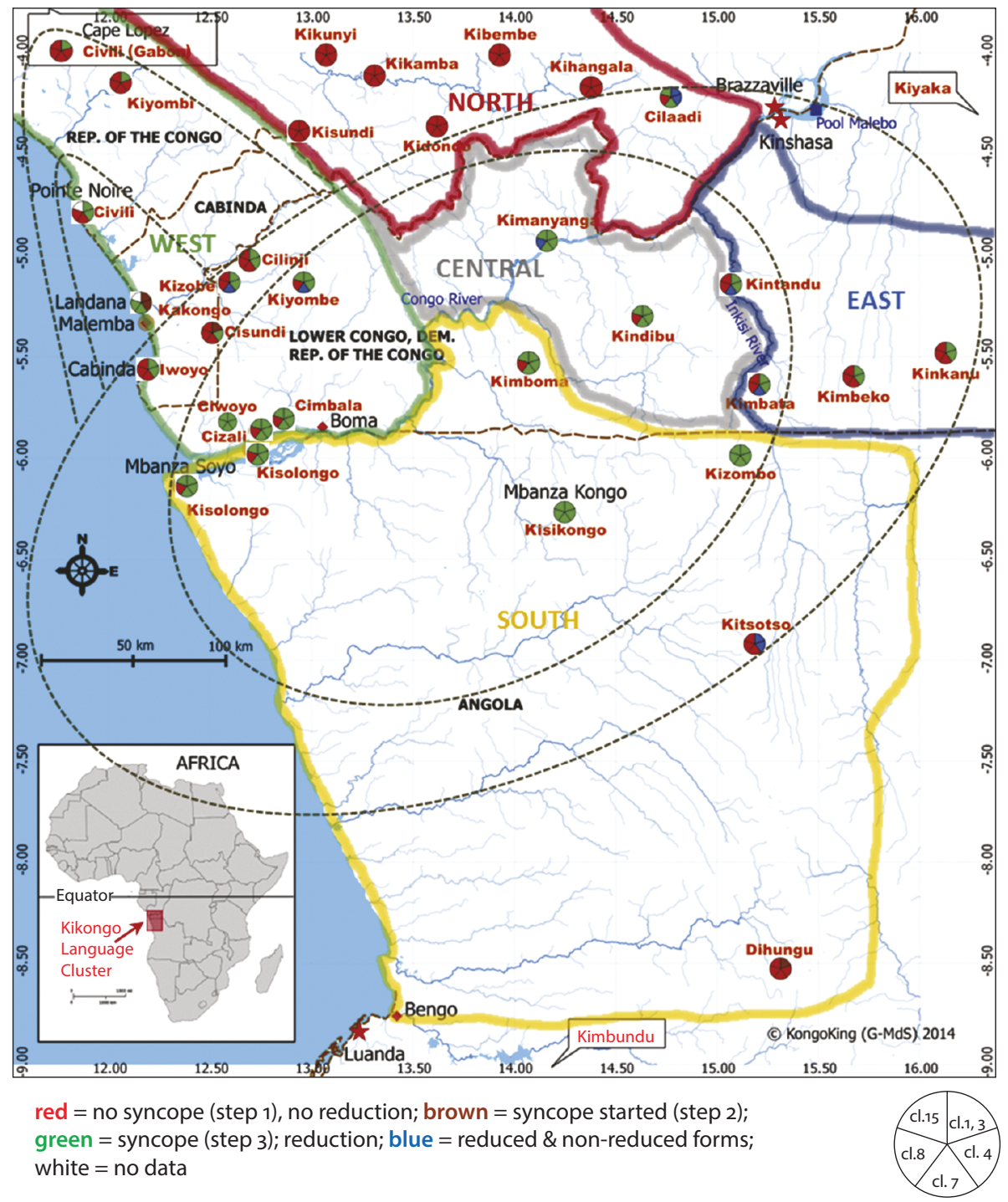

Map 3. Prefix reduction in the KLC, 1880s - present 